\title{
Monthly and spatially resolved black carbon emission inventory of India: uncertainty analysis
}

\author{
Umed Paliwal $^{1}$, Mukesh Sharma ${ }^{1}$, and John F. Burkhart ${ }^{2,3}$ \\ ${ }^{1}$ Department of Civil Engineering, Indian Institute of Technology, Kanpur, 208016, India \\ ${ }^{2}$ Department of Geosciences, University of Oslo, Norway \\ ${ }^{3}$ Sierra Nevada Research Institute, University of California, Merced, California, USA
}

Correspondence to: John F. Burkhart (john.burkhart@geo.uio.no)

Received: 2 December 2015 - Published in Atmos. Chem. Phys. Discuss.: 26 January 2016

Revised: 31 August 2016 - Accepted: 7 September 2016 - Published: 5 October 2016

\begin{abstract}
Black carbon (BC) emissions from India for the year 2011 are estimated to be $901.11 \pm 151.56 \mathrm{Gg} \mathrm{yr}^{-1}$ based on a new ground-up, GIS-based inventory. The grid-based, spatially resolved emission inventory includes, in addition to conventional sources, emissions from kerosene lamps, forest fires, diesel-powered irrigation pumps and electricity generators at mobile towers. The emissions have been estimated at district level and were spatially distributed onto grids at a resolution of $40 \times 40 \mathrm{~km}^{2}$. The uncertainty in emissions has been estimated using a Monte Carlo simulation by considering the variability in activity data and emission factors. Monthly variation of $\mathrm{BC}$ emissions has also been estimated to account for the seasonal variability. To the total $\mathrm{BC}$ emissions, domestic fuels contributed most significantly (47\%), followed by industry (22\%), transport (17\%), open burning $(12 \%)$ and others $(2 \%)$. The spatial and seasonal resolution of the inventory will be useful for modeling BC transport in the atmosphere for air quality, global warming and other process-level studies that require greater temporal resolution than traditional inventories.
\end{abstract}

\section{Introduction}

Carbonaceous aerosols, defined as black carbon (BC) and also known as elemental carbon (EC) and organic carbon (OC) (Pachauri et al., 2013), form a significant and highly variable component of atmospheric aerosols. Neither BC nor $\mathrm{OC}$ has a precise chemical definition. OC includes numerous organic compounds, some of which are found to be carcinogenic, such as poly-aromatic hydrocarbons (PAHs) (Menzie et al., 1992; Pedersen et al., 2005). The Intergovernmen- tal Panel on Climate Change (IPCC) defines BC as "Operationally defined aerosol species based on measurement of light absorption and chemical reactivity and/or thermal stability" (IPCC, 2013). BC is released from incomplete combustion of carbonaceous fuels such as agricultural and forest biomass, coal, diesel, etc. The type of combustion greatly affects the $\mathrm{BC}$ emission rates; notably, inefficient combustion emits more $\mathrm{BC}$ than efficient combustion for the same type of fuel. Aside from air quality and health effects, there are a number of climate impacts of $\mathrm{BC}$ emissions including alterations to temperature through atmospheric adsorption, modifications to precipitation timing and increased melting of snow (Meehl et al., 2008; Flanner et al., 2007; Ramanathan and Carmichael, 2008; Quinn et al., 2007; Koch and Del Genio, 2010; Bond et al., 2013), all of which are consequential to global warming. $\mathrm{BC}$ has been implied to be the second-largest contributor to global warming after $\mathrm{CO}_{2}(\mathrm{Ra}-$ manathan and Carmichael, 2008). There is a current debate that due to the short life span of $\mathrm{BC}$, the $\mathrm{BC}$ atmospheric concentration will drop quickly if emissions are reduced, thereby potentially offering a rapid means to slow down global warming (Bond and Sun, 2005; Grieshop et al., 2009; Kopp and Mauzerall, 2010; Bowerman et al., 2013).

India is a rapidly growing economy with massive future growth potential. The total energy and coal consumption has almost doubled from 2001 to 2011 (IEA, 2012). The emissions of particulate matter or aerosols have been rising over the last few decades and are expected to increase in the future as well, due to rapid industrial growth and slower emission control measures (Menon et al., 2010). Recent studies (Yasunari et al., 2013; Lau et al., 2010) have shown that the deposition of $\mathrm{BC}$ in the Himalayan glaciers has accelerated 
their melting. While $\mathrm{BC}$ is a source of warming on a global scale, on a regional scale, it has adverse effects on air quality and human health. BC is a major part of particulate matter, with a size less than 2.5 micron $\left(\mathrm{PM}_{2.5}\right)$, and like other $\mathrm{PM}_{2.5}$ particles, it is small enough to be inhaled. According to the World Health Organization (WHO), exposure to BC can lead to cardiopulmonary morbidity and mortality. WHO also suggests that BC may act as a universal carrier of chemicals of varying toxicity to lungs (Janssen et al., 2012). Understanding the sources of $\mathrm{BC}$, their emissions and spatial distribution is important both for policy making and improving climate modeling. Preparation of an accurate emission inventory is the first step towards developing robust air pollution control strategies. Air quality measurement stations are installed at limited locations and are unable to provide a measure of spatial variability. However, observations coupled with air quality models can provide comprehensive information about the impact of various sources on ambient air quality and their spatial variability. The greatest benefit of these models is gained after preparing an accurate emission inventory, validating the models with observations and thereby enabling a tool for improved control measures.

Although there have been several emission inventories developed for $\mathrm{BC}$ in the last decade, the estimates are variable without any knowledge of uncertainties. Model-predicted BC concentrations over India are 2 to 6 times lower than the observed concentrations (Ganguly et al., 2009; Nair et al., 2012; Bond et al., 2013; Moorthy et al., 2013). Further the current estimates vary considerably. The Reanalysis of tropospheric chemical composition (RETRO) emission inventory (Schultz et al., 2007, 2008) estimated BC emissions in 2010 as $697 \mathrm{Gg} \mathrm{yr}^{-1}$; the System of Air Quality Weather Forecasting and Research (SAFAR) emission inventory (Sahu et al., 2008) estimated them as $1119 \mathrm{Gg} \mathrm{yr}^{-1}$ for the year 2011; Klimont et al. (2009) report $\mathrm{BC}$ emissions as $1104 \mathrm{Gg} \mathrm{yr}^{-1}$ for the year 2010, and $\mathrm{Lu}$ et al. (2011) reported them as $1015 \mathrm{Gg} \mathrm{yr}^{-1}$ for the year 2010 . Not only is there a need to get a meaningful total estimate but there is also a need to assess the uncertainty and spatial variability associated with these estimates. Most of the emission inventories provide yearly emissions and do not account for sub-annual temporal emission variability, which leads to inaccurate impact assessments. To improve the nature of advanced numerical forecasts of impacts from aerosol pollution, we have developed an emission inventory at a monthly resolution.

The objective of this study is to prepare a sub-annual, high spatial resolution, comprehensive spatially gridded emission inventory of BC emissions for India for the base year 2011. The approach is a ground-up inventory based on activity data from various sectors, combined with emission factors. While results are provided for 1 year, the frequency and distribution should be general enough such that coupled with growth forecasts, multiyear use could be valid. In this study, we have prepared a district-wise emission inventory available on a $40 \times 40 \mathrm{~km}^{2}$ grid. We have accounted for all the

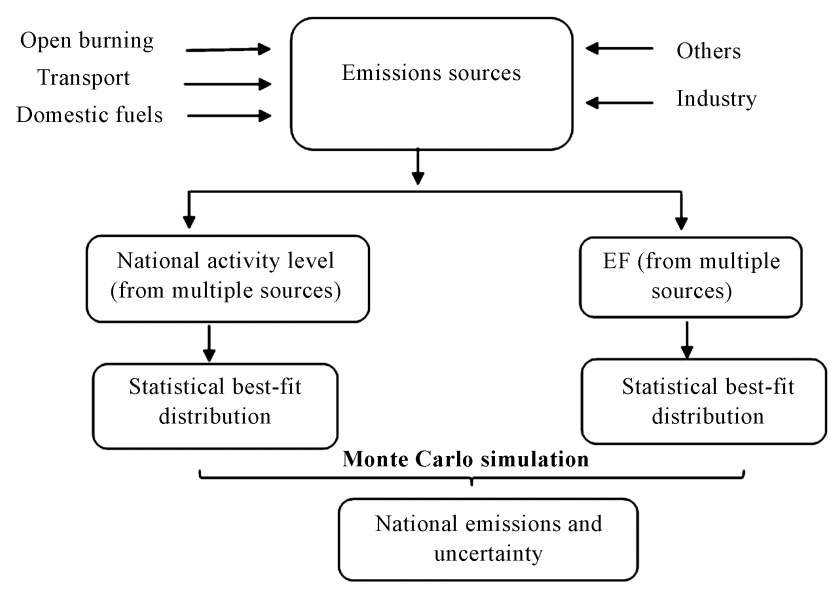

Figure 1. Methodology for national emissions.

major sources of BC emissions in India. For example, emissions from kerosene lamps (Lam et al., 2012) and forest fires, which were previously unaccounted for in many emission inventories, have been included. Monthly variation of BC emissions has also been estimated to provide better input for air quality models. We employ a unique approach to quantify uncertainty in the emissions by considering variability in (i) activity data from various sources and (ii) emission factors (EFs). Specifically, probabilistic distributions were assigned to both activity data and EFs. By employing a Monte Carlo simulation, several activity levels and EFs were generated to arrive at emissions (by multiplying generated activity data and $\mathrm{EF}$ ), which could be interpreted in terms of a mean value and associated uncertainty.

In Sect. 2 we present the methods used in our analysis. Sect. 3 describes the source sectors and activity data we considered. A description of the magnitude of emissions from each sector is presented in Sect. 4.

\section{Methods}

Our approach may be divided into two parts. Figure 1 presents the methodology for developing national emissions and their uncertainty, and Fig. 2 presents the approach for extracting gridded emissions. For estimating national emissions, a thorough review of multiple national activity data and EFs for each source was conducted from available published and unpublished sources (Table 1 and Table 2).

We fit a probability distribution function (PDF) to both national activity data and EFs from a pool of distributions on the basis of a Kolomogorov-Smirnov test (KS statistic) using Mathwave Technologies EasyFit ${ }^{\odot}$ software (Mathwave Technologies, 2015). Using the optimal PDF for both variables (EFs and activity data) for each source, we generated 1000 estimates of each variable from each of the two distributions. Further increasing the number of generations did not change the mean and the variance of the emissions. 


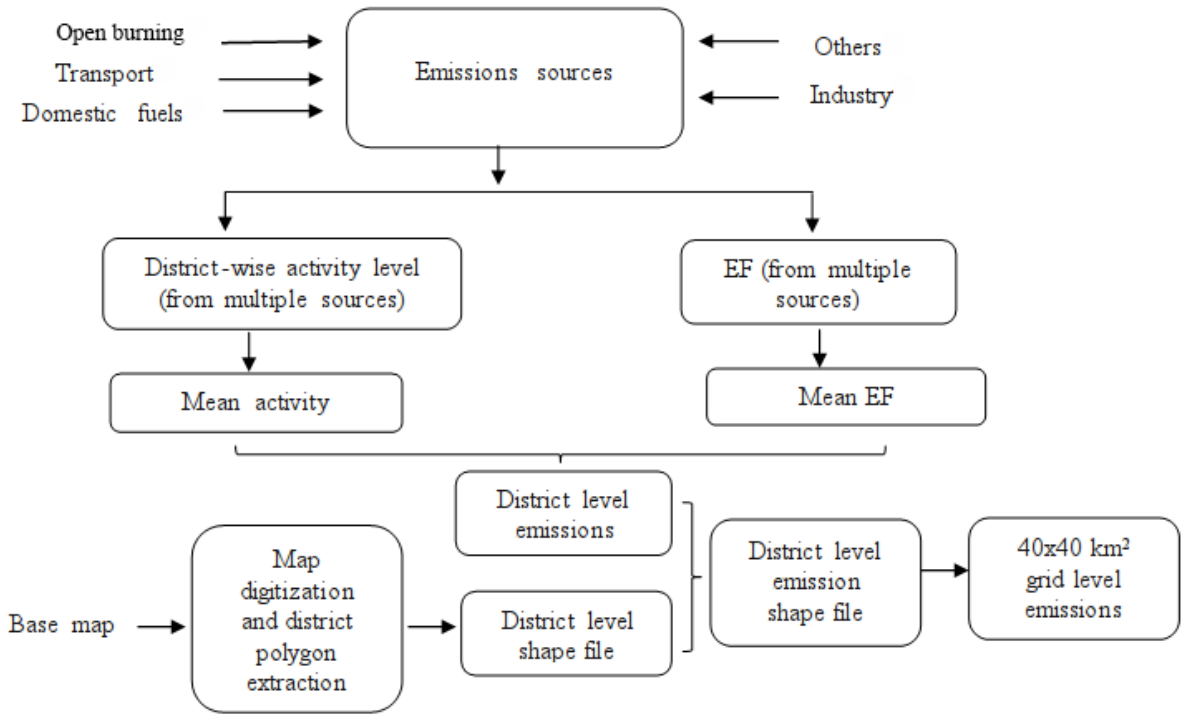

Figure 2. Methodology for preparing gridded emissions.

For activity data that had only one source of information, a normal distribution with a mean as the data point and standard deviation of $20 \%$ of the data point was assumed based on the experience regarding other data sets (Table 1). Bestfit distributions were only determined from the KS statistic if the number of data points exceeded five; in other cases, a uniform distribution was assumed.

For preparing the gridded inventory, the emissions were first estimated within a Geographic Information System (GIS) using polygons at the district level. Polygons were subsequently divided into $40 \times 40 \mathrm{~km}^{2}$ grid elements and were proportionally assigned emissions based on the area. The area for grid elements spanning a district border was accounted for. Emissions from industry (point data) were added directly to the overlying grid based on available location coordinates for the source. For the road transport (network) sector, the data from at the district level were distributed along the road network and then assigned to overlying grids, proportionally to the length of road in the grid element. Interpolation of the data was not conducted, as this would lead to erroneous georeferencing of emissions, particularly in the case of point data. More details are found in the subsections below.

For the national level annual inventory, Monte Carlo simulations were undertaken to specifically estimate mean emissions and uncertainties, whereas at the district level the mean of the EFs and district level activity data were used to arrive at average emission levels. An image of the political map of India (Census of India, 2011) was georeferenced using Google Earth, and 640 districts were digitized as polygons to generate a national level shapefile. This shapefile had an attribute table containing all the districts, and yearly emission quantities were recorded for each district. The shapefile and polygon data were resampled to a $40 \times 40 \mathrm{~km}^{2}$ grid by calculating the area of each portion of the districts within a grid element and attributing that portion of the emissions to the grid. As a grid cell may overlay over more than one district, the overall emission in each cell was calculated by summing up part of emissions from each contributing portion from the district, based on area of the district within the grid cell and emission density for the district:

$E_{\text {cell }}=\sum_{i=1}^{n}\left(\rho_{i} \cdot A_{i}\right)$,

where $n$ is the total number of districts within each grid cell, $\rho$ is the emission density $\left(\mathrm{g} \mathrm{s}^{-1} \mathrm{~m}^{-2}\right)$ for each district and $A$ is the area of the district $\left(\mathrm{m}^{2}\right)$ within the grid. Emission density (mass / time area) was calculated by dividing the BC emission in the district with the total area of the district.

\section{Source sectors and activity data}

The emissions sources considered in this study can be broadly categorized into five sectors: open burning, industry, transport, domestic fuel and others. In the following section we define the activity data and emission sources considered within each sector. All the emission sources identified by Reddy and Venkataraman (2002a, b) and Sonkar (2011) were included in this study. Also, some of the highly emitting sources identified in the recent literature (kerosene lamps, diesel generators and irrigation pumps) were also considered. Tables 1 and 2 provide an overview of activity data and EFs for the sources considered. 
Table 1. Mean activity data, standard deviation and best-fit probabilistic distribution.

\begin{tabular}{|c|c|c|c|}
\hline Subsector & Activity level & Mean \pm SD & Distribution \\
\hline \multicolumn{4}{|l|}{ Open burning $\left(\mathrm{Mt} \mathrm{yr}^{-1}\right)$} \\
\hline Crop residue burning & $99.93^{1,2}, 89.79^{1,3}, 90.94^{1,4}$ & $93.56 \pm 4.96$ & Uniform \\
\hline Forest fire* & $47.83^{5}$ & $47.83 \pm 9.56$ & Normal \\
\hline Garbage burning & $3.90^{2,6}, 2.51^{2,6,7,8,9}$ & $3.2 \pm 0.76$ & Uniform \\
\hline \multicolumn{4}{|l|}{ Industry $\left(\mathrm{Mt} \mathrm{yr}^{-1}\right)$} \\
\hline Brick* & $474^{10}$ & $474 \pm 237$ & Normal \\
\hline Steel* & $40.05^{11}$ & $40.05 \pm 8.01$ & Normal \\
\hline Sugar* & $77.1^{12,13}$ & $77.1 \pm 15.42$ & Normal \\
\hline Cement* & $28.06^{14}$ & $28.06 \pm 5.61$ & Normal \\
\hline Power coal* & $380.91^{15}$ & $380.91 \pm 76.18$ & Normal \\
\hline Power diesel* & $0.71^{15}$ & $0.71 \pm 0.01$ & Normal \\
\hline \multicolumn{4}{|l|}{ Transport (billion $\mathrm{km} \mathrm{yr}^{-1}$ ) } \\
\hline Bus & $38.77^{16,17}, 39.3916^{16,18}, 32.8316^{16,19}$ & $35.46 \pm 3.94$ & Uniform \\
\hline Car & $128^{16,17}, 196.27^{16,18}, 130.85^{16,19}, 167.87^{16,21}$ & $155.06 \pm 29.76$ & Uniform \\
\hline LMV & $104.22^{16,17}, 131.51^{16,18}, 65.75^{16,19}$ & $105.32 \pm 22.74$ & Uniform \\
\hline $\mathrm{LCV}$ & $78.55^{16,17}, 99.12^{16,18}, 74.34^{16,19}$ & $111.37 \pm 38.70$ & Uniform \\
\hline Truck & $122.99^{16,17}, 87.30^{16,20}, 125.50^{16,21}$ & $109.60 \pm 16.72$ & Uniform \\
\hline Taxi & $38.25^{16,17}, 40.26^{16,18}, 48.32^{16,19}, 16.91^{16,21}, 60.44^{16,22}, 51.01^{16,23}$ & $42.52 \pm 14.86$ & Gumbel \\
\hline Two wheeler & $450.8^{16,17}, 764.07^{16,18}, 481.36^{16,21}, 2062.89^{16,22}, 313.26^{16,23}$ & $814.50 \pm 716.18$ & Uniform \\
\hline Tractor and trailer & $11.08^{16,17}, 26.38^{16,18}$ & $18.73 \pm 8.38$ & Uniform \\
\hline Railway coal $\left(\mathrm{kt} \mathrm{yr}^{-1}\right)^{*}$ & $1^{24}$ & $1 \pm 0.02$ & Normal \\
\hline Railway diesel $\left(\mathrm{kt} \mathrm{yr}^{-1}\right)^{*}$ & $21.06^{24}$ & $21.06 \pm 42.10$ & Normal \\
\hline Shipping HSDO $\left(\mathrm{kt} \mathrm{yr}^{-1}\right)^{*}$ & $0.11^{25,26}$ & $0.11 \pm 0.02$ & Normal \\
\hline Shipping fuel oil $\left(\mathrm{kt} \mathrm{yr}^{-1}\right)^{*}$ & $80^{25,26}$ & $80 \pm 16$ & Normal \\
\hline Shipping LDO $\left(\mathrm{kt} \mathrm{yr}^{-1}\right)^{*}$ & $0.36^{25,26}$ & $0.36 \pm 0.07$ & Normal \\
\hline Aviation LTO $\left(\mathrm{kt} \mathrm{yr}^{-1}\right)^{*}$ & $514.16^{2,25,27,28}$ & $514.16 \pm 102.83$ & Normal \\
\hline Aviation cruise $\left(\mathrm{kt} \mathrm{yr}^{-1}\right)^{*}$ & $1505.83^{2,25,27,28}$ & $1505.83 \pm 301.16$ & Normal \\
\hline \multicolumn{4}{|l|}{ Domestic fuel (Mt yr $\left.{ }^{-1}\right)$} \\
\hline Dung cake & $144.84^{29}, 75.62^{30}$ & $110.23 \pm 37.91$ & Uniform \\
\hline Agriculture residue & $125.34^{29}, 81.25^{30}$ & $103.30 \pm 24.14$ & Uniform \\
\hline Firewood & $209.99^{31}, 281.99^{29}, 193.87^{30}$ & $228.62 \pm 41.96$ & Uniform \\
\hline Coal* & $4.77^{31}$ & $4.77 \pm 0.95$ & Normal \\
\hline Kerosene cooking* & $4.57^{31,32}$ & $4.57 \pm 0.91$ & Normal \\
\hline $\mathrm{LPG}^{*}$ & $12.37^{31}$ & $12.37 \pm 2.47$ & Normal \\
\hline Kerosene lamps & $1.68^{32}, 1.21^{31,32}$ & $1.45 \pm 0.25$ & Uniform \\
\hline \multicolumn{4}{|l|}{ Others $\left(\mathrm{Mt} \mathrm{yr}^{-1}\right)$} \\
\hline Irrigation pumps* & $2.11^{25}$ & $2.11 \pm 0.42$ & Normal \\
\hline Diesel generators (mobile towers)* & $1.12^{25,33}$ & $1.12 \pm 0.22$ & Normal \\
\hline Diesel generators (other)* & $2.28^{25,33}$ & $2.28 \pm 0.45$ & Normal \\
\hline \multicolumn{4}{|c|}{ 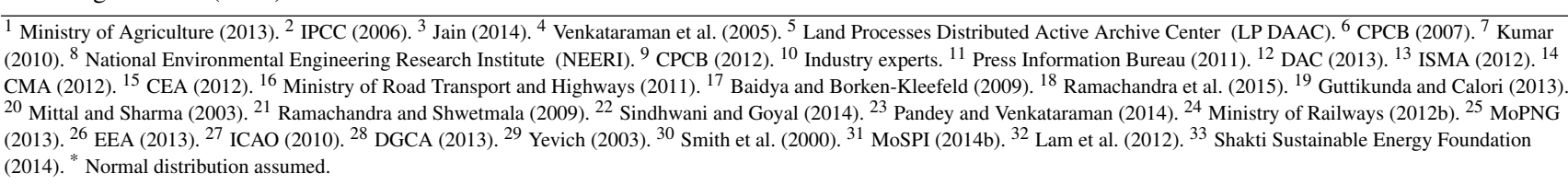 } \\
\hline
\end{tabular}


Table 2. Mean EFs, standard deviation and best-fit probabilistic distribution.

\begin{tabular}{|c|c|c|c|}
\hline Subsector & EFs used & Mean $\mathrm{EF} \pm \mathrm{SD}$ & Best-fit distribution \\
\hline \multicolumn{4}{|l|}{ Open burning $\left(\mathrm{g} \mathrm{kg}^{-1}\right)$} \\
\hline Crop residue burning & $0.69^{1}, 0.78^{2}, 0.73^{3}, 0.47^{4}, 0.75^{2}$ & $0.69 \pm 0.19$ & Dagum \\
\hline Forest fire & $0.56^{1}, 0.98^{4}, 0.99^{5}, 0.56^{6}$ & $0.76 \pm 0.21$ & Error \\
\hline Garbage burning & $0.65^{7}, 0.37^{8}$ & $0.51 \pm 0.15$ & Uniform \\
\hline \multicolumn{4}{|l|}{ Industry $\left(\mathrm{g} \mathrm{kg}^{-1}\right)$} \\
\hline Brick & $0.11^{9}, 0.27^{9}, 0.09^{9}$ & $0.16 \pm 0.09$ & Uniform \\
\hline Steel & $0.32^{3}, 1.1-1.58^{10}, 0.224^{11}, 0.23-0.13^{12}, 0.06^{5}, 0.0095^{13}$ & $0.45 \pm 0.51$ & Log Pearson 3 \\
\hline Sugar & $1.2^{14}, 0.7^{15}$ & $0.95 \pm 0.27$ & Uniform \\
\hline Cement & $0.32^{3}, 1.1-1.58^{10}, 0.224^{11}, 0.23-0.13^{12}, 0.06^{5}, 0.0095^{13}$ & $0.45 \pm 0.51$ & Log Pearson 3 \\
\hline Power coal & $0.003-0.032^{16}, 0.077^{13}, 0.0029^{11}, 0.002^{5}, 0.06^{5}$ & $0.03 \pm 0.03$ & Gamma (3P) \\
\hline Power diesel & $0.25^{11}, 0.15^{8}, 0.06^{13}$ & $0.15 \pm 0.08$ & Uniform \\
\hline \multicolumn{4}{|l|}{ Transport $\left(\mathrm{g} \mathrm{km}^{-1}\right)$} \\
\hline Bus & $0.35^{17,18}, 0.8^{18,19}, 0.225^{18,20}, 0.61^{18,21}$ & $0.49 \pm 0.24$ & Uniform \\
\hline Car & $0.16^{22}, 0.17^{17,18}, 0.05^{18,19}, 0.07^{18,20}, 0.16^{18,21}$ & $0.09 \pm 0.06$ & Uniform \\
\hline LMV & $0.16^{22}, 0.138^{17,18}, 0.17^{18,21}$ & $0.15 \pm 0.01$ & Uniform \\
\hline LCV & $0.27^{17,18}, 0.13^{18,19}, 0.16^{18,21}$ & $0.19 \pm 0.07$ & Uniform \\
\hline Truck & $0.61^{17,18}, 0.26^{18,19}, 0.19^{18,20}, 0.31^{18,21}$ & $0.34 \pm 0.17$ & Uniform \\
\hline Taxi & $0.01^{22}, 0.06^{17,18}, 0.076^{18,20}, 0.057^{18,21}$ & $0.05 \pm 0.03$ & Uniform \\
\hline Two wheeler & $0.013^{23}, 0.012^{17,18}, 0.038^{18,19}, 0.023^{18,20}$ & $0.02 \pm 0.01$ & Uniform \\
\hline Tractor and trailer* & $1.24^{23}$ & $1.24 \pm 0.25$ & Normal \\
\hline Railway coal $\left(\mathrm{g} \mathrm{kg}^{-1}\right)$ & $1.83^{13}, 3^{8}$ & $2.415 \pm 0.33$ & Uniform \\
\hline Railway diesel $\left(\mathrm{g} \mathrm{kg}^{-1}\right)$ & $1.53^{24}, 0.51^{8}, 0.29^{13}$ & $0.78 \pm 0.59$ & Uniform \\
\hline Shipping HSDO $\left(\mathrm{g} \mathrm{kg}^{-1}\right)$ & $0.85^{25}, 1.19^{8}, 1.32^{26}, 0.36^{25}$ & $0.78 \pm 0.49$ & Gen. extreme value \\
\hline Shipping fuel oil $\left(\mathrm{g} \mathrm{kg}^{-1}\right)$ & $0.38^{25}, 0.36^{25}, 0.97^{25}, 0.85^{25}, 1.19^{8}, 1.32^{26}$ & $0.72 \pm 0.40$ & Wakeby \\
\hline Shipping LDO $\left(\mathrm{g} \mathrm{kg}^{-1}\right)$ & $0.85^{25}, 1.19^{8}, 1.32^{26}$ & $0.89 \pm 0.46$ & Uniform \\
\hline Aviation LTO $\left(\mathrm{g} \mathrm{kg}^{-1}\right)$ & $0.08-0.1^{27}$ & $0.09 \pm 0.01$ & Uniform \\
\hline Aviation cruise $\left(\mathrm{g} \mathrm{kg}^{-1}\right)$ & $0.02-0.1^{27}$ & $0.06 \pm 0.02$ & Uniform \\
\hline \multicolumn{4}{|l|}{ Domestic fuel $\left(\mathrm{g} \mathrm{kg}^{-1}\right)$} \\
\hline Dung cake & $0.53^{8}, 1^{14}, 0.8^{28}, 0.25^{4}, 0.49^{29}, 0.18^{30}, 0.12^{31}, 0.4^{15}$ & $0.47 \pm 0.31$ & Gen. extreme value \\
\hline Agriculture residue & $\begin{array}{l}0.43^{32}, 0.66^{11}, 0.75^{2}, 0.47^{4}, 0.37^{29}, 1^{8}, 1.3^{33}, 0.24^{30}, 1.38^{34} \\
0.6^{31}, 0.9^{31}\end{array}$ & $0.74 \pm 0.37$ & Gen. extreme value \\
\hline Firewood & $\begin{array}{l}1^{3}, 0.59^{1}, 0.41^{4}, 0.7^{32}, 1.2^{14}, 1^{28}, 0.85^{8}, 0.6^{31}, 0.35^{29}, 1.1^{33} \\
0.25^{30}, 0.83^{35}, 1.33^{6}, 0.7^{36}\end{array}$ & $0.78 \pm 0.32$ & Gen. extreme value \\
\hline Coal & $\begin{array}{l}1.91^{3}, 2.84^{10}, 1.83^{4}, 5^{8}, 0.28^{37}, 2.295^{24}, 0.8^{11}, 0.3^{11}, 0.69^{11} \\
0.79^{11}, 0.32^{11}, 0.497^{11}, 0.07^{36}, 5.4^{15}\end{array}$ & $1.64 \pm 1.73$ & Pearson $6(4 \mathrm{P})$ \\
\hline Kerosene cooking & $0.16^{4}, 0.02^{15}$ & $0.18 \pm 0.02$ & Uniform \\
\hline LPG & $0.067^{11}, 0.01^{15}$ & $0.04 \pm 0.03$ & Uniform \\
\hline Kerosene lamps & $66^{38}, 89^{38}, 72^{38}, 110^{38}, 79^{38}, 94^{38}, 89^{38}, 76^{38}$ & $84.37 \pm 14.05$ & Pearson $6(4 \mathrm{P})$ \\
\hline \multicolumn{4}{|l|}{ Others $\left(\mathrm{g} \mathrm{kg}^{-1}\right)$} \\
\hline Irrigation pumps & $3.18^{24}, 3.96^{8}$ & $3.56 \pm 0.22$ & Uniform \\
\hline Diesel generators & $3.41^{24}, 3.96^{8}$ & $3.68 \pm 0.16$ & Uniform \\
\hline
\end{tabular}

${ }^{1}$ Andreae and Merlet (2001). ${ }^{2}$ Turn et al. (1997). ${ }^{3}$ Streets et al. (2001). ${ }^{4}$ Reddy and Venkataraman (2002a). ${ }^{5}$ Qin and Xie (2011). ${ }^{6}$ Zhang et al. (2013). ${ }^{7}$ Akagi et al. (2011) ${ }^{8}$ Bond et al. (2004). ${ }^{9}$ Weyant et al. (2014). ${ }^{10}$ Cooke et al. (1999). ${ }^{11}$ Ni et al. (2014). ${ }^{12}$ Novakov (2003). ${ }^{13}$ Reddy and Venkataraman (2002b). ${ }^{14}$ Liousse et al. (1996). ${ }^{15}$ Pandey et al. (2014). ${ }^{16}$ Streets et al. (2003). ${ }^{17}$ ARAI (2008). ${ }^{18}$ Chow et al. (2011). ${ }^{19}$ Borken et al. (2008). ${ }^{20}$ Baidya and Borken-Kleefeld (2009). ${ }^{21}$ Mittal and Sharma (2003). ${ }^{22}$ Reynolds and Kandlikar (2008). ${ }^{23}$ TERI (The Energy and Resources Institute). ${ }^{24}$ Ito and Penner (2005). ${ }^{25}$ Lack et al. (2009). ${ }^{26}$ Bond et al. (2007). ${ }^{27}$ Hendricks et al. (2004). ${ }^{28}$ Cachier (1998). ${ }^{29}$ Saud et al. (2012). ${ }^{30}$ Sen et al. (2014). ${ }^{31}$ Habib et al. (2004). ${ }^{32}$ Li et al. (2009). ${ }^{33}$ Parashar et al. (2005). ${ }^{34}$ Shen et al. (2010). ${ }^{35}$ Shen et al. (2012). ${ }^{36}$ Chen et al. (2009). ${ }^{37}$ Chen et al. (2005). ${ }^{38}$ Lam et al. (2012). ${ }^{*}$ Normal distribution assumed. 


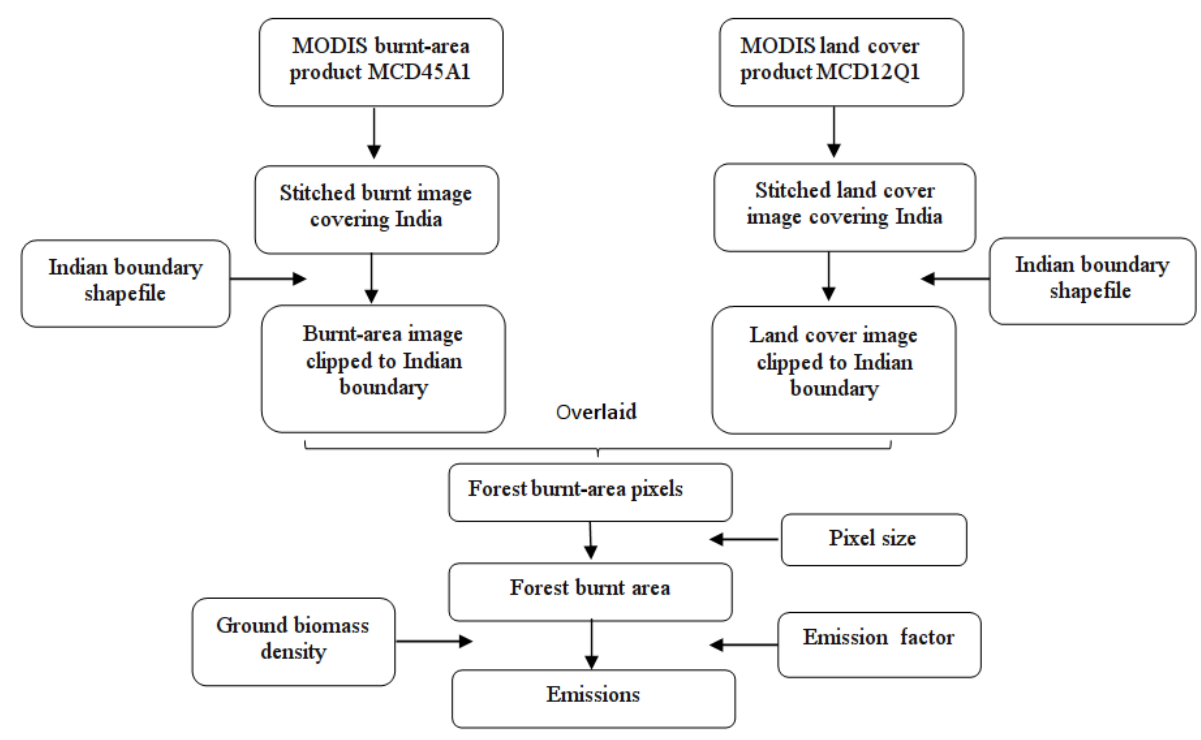

Figure 3. Flow chart for the calculation of forest fire emissions based on MODIS products.

\subsection{Open burning}

The open-burning sector includes forest fire emissions, open solid-waste burning and agriculture residue burning.

\subsubsection{Forest fire}

According to the 2013 Forest Survey of India (FSI), around $50 \%$ of the forest area of India is prone to forest fires (FSI, 2013). There is a strong seasonality associated with forest fires in India, with the majority of fires occurring in the months from February to July. The causes of forest fire in India are both man-made and natural, natural causes being the high temperature and low humidity. Man-made causes include accidental fires and forest burnt for shifting cultivation. The forest fire burnt area in this study was determined using the MODIS (Moderate Resolution Imaging Spectroradiometer) monthly burnt-area product MCD45A1, which has a resolution of $500 \mathrm{~m}$ (Land Processes Distributed Active Archive Center, LP DAAC). MODIS product MCD12Q1 (500 m resolution) was used to define forest cover. The burnt-area and land cover products were retrieved from the LP DAAC website (https://lpdaac.usgs.gov/).

The methodology used for emission estimation is presented in Fig. 3. The burnt-area (MCD45A1) and land cover product (MCD12Q1) are available in Hierarchical Data Format - Earth Observing System (HDF-EOS) and have an Earth gridded tile area of $1200 \mathrm{~km} \times 1200 \mathrm{~km}$. They were stitched to cover the whole geographical extent of India. The stitched products were converted to GeoTIFF image format and clipped to the Indian domain using the ESRI shapefile of the boundary of India. The same methodology was used for the burnt-area product as well as the vegetation cover. Monthly burnt area GeoTIFF images were overlayed on land cover images to determine the monthly forest burnt-area pixels and subsequently the forest area burnt. Dry mass per unit area of forest burnt was taken to be $5.2 \mathrm{~kg} \mathrm{~m}^{-2}$ (Joshi, 1991). Emissions were distributed district-wise according to the number of incidents of forest fire occurring in that district in 2011. The data of district-wise incidents of forest fire were taken from the most recent forest survey (FSI, 2015). Figure 4 shows the land cover image and burnt-area image used for estimating the forest fire burnt area in January 2011. It can be noted that the emissions from this subsector can easily be updated for future years using the latest MODIS burnt area and land cover products and following the aforementioned methodology.

\subsubsection{Municipal solid-waste open burning}

The dry weight content of Indian municipal solid waste (MSW) was estimated using the MSW composition in India (CPCB, 2007) and the dry matter content of MSW components per IPCC (2006). Indian MSW is primarily composed of vegetables $(40 \%)$, stones $(42 \%)$ and grass $(4 \%)$, which have a dry matter content of 40,100 and $40 \%$, respectively. Dry matter content was estimated to be $67.6 \%$.

State-wise generated and collected MSW was derived from the Central Pollution Control Board (CPCB) Municipal Solid Waste Management Report 2012 (CPCB, 2012). The MSW generated was distributed among districts according to their urban population. For the states where MSW collected volume was not available, a value of $60 \%$ of the total MSW generated was assumed (Kumar, 2010). The total MSW openly burnt was taken to be $10 \%$ of the collected waste and $2 \%$ of the uncollected waste (National Environmental Engineering Research Institute, NEERI). To provide a second approach for the uncertainty analysis, per capita 


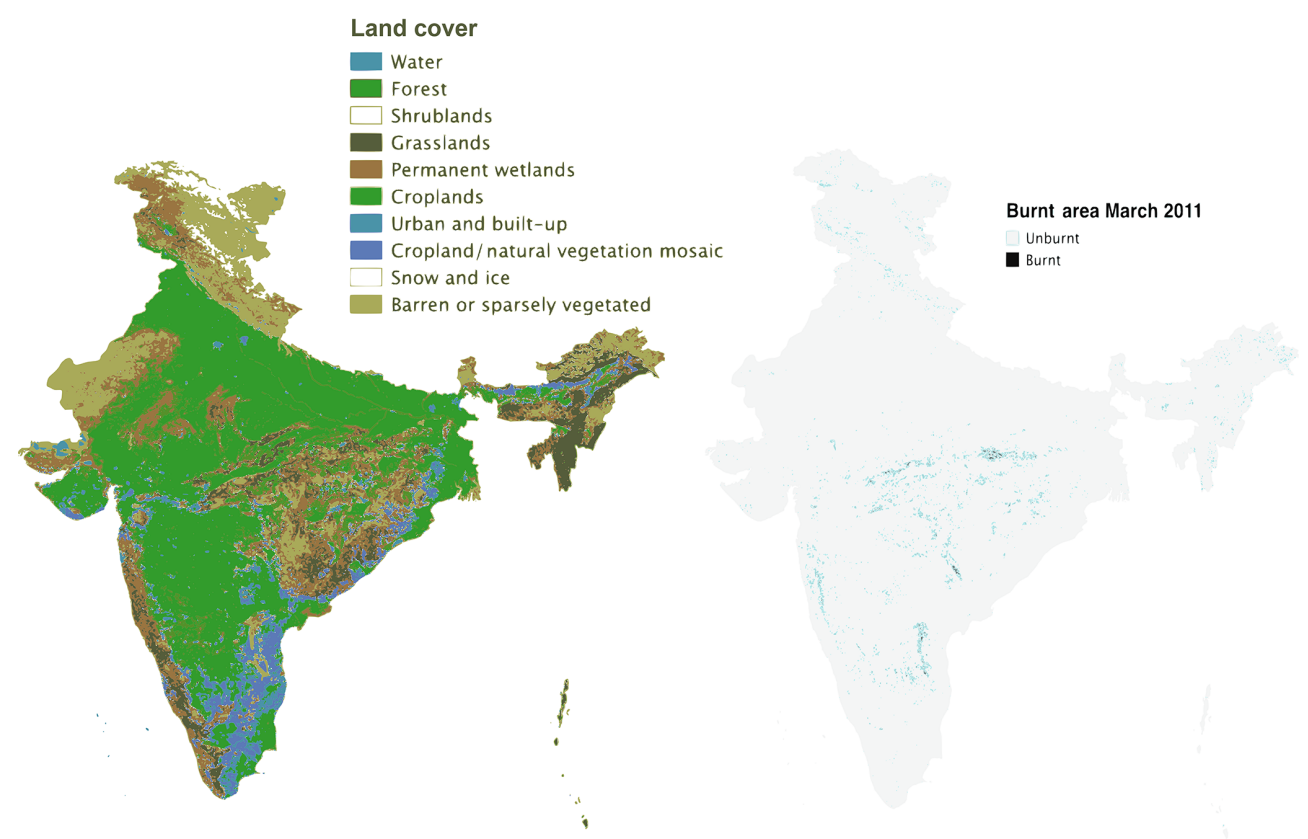

Figure 4. Land cover and burnt area for March 2011.

waste generation in India and the fraction burnt were taken from IPCC (2006). The 2011 census population data were used to provide the urban population of the district. From this, the total MSW burnt for each district was taken as the product of the IPCC guideline results and the urban population.

\subsubsection{Agricultural residue burning}

India generates a large amount of agricultural residues (e.g., waste biomass) every year after harvesting crops. These residues are used as domestic and industrial fuel, fodder for animals, etc., but a large amount remains unutilized in the fields. The quickest and easiest way for the farmers to manage this waste is to burn it. Figure 5 shows a flowchart for estimating emissions from crop residue burning.

The state-wise production of cotton, jowar, barley, jute, ragi, rice, maize, bajra, groundnut, sugarcane, wheat and rapeseed and mustard in 2011 was taken from the Ministry of Agriculture (2012) (http://eands.dacnet.nic.in/). The crop production was distributed among districts of that state according to the net sown area (Ministry of Agriculture, 2011) in that district. Emission from crop residue burning was calculated using the following equation as suggested by Jain (2014).

$\mathrm{ECRB}=\sum_{i=1}^{D} \sum_{j=1}^{C}\left(P \cdot Q \cdot R \cdot S \cdot T \cdot \mathrm{EF}_{\mathrm{BC}}\right)$,

where ECRB is the emissions from crop residue burning. The summation is done over the districts, $D$, and for each type of crop, $C$. The emission is then calculated from the product of crop production $(P)$, residue-to-crop ratio $(Q)$, dry matter fraction $(R)$, the fraction burnt $(S)$, the fraction actually oxidized $(T)$ and finally the EF for BC. Three estimates of crop residue burnt $(P \cdot Q \cdot R \cdot S \cdot T)$ were obtained by varying $Q, R$ and $S$, while holding $P$ and $T$ constant for all the three estimates. In the first estimate, the residue-to-crop ratio $(Q)$, dry matter fraction $(R)$ and fraction burnt $(S)$ were taken from Jain (2014). In the second estimate, the residue-to-crop ratio and dry matter fraction was kept the same and the fraction burnt was taken as 0.25 for all the crops (IPCC, 2006). In the third estimate, the residue-to-crop ratio and dry matter fraction was taken from Venkataraman et al. (2006), and the fraction burnt was kept as 0.25 (IPCC, 2006). This provided us with three estimates of the total crop residue burnt in the fields (Table 1).

\subsection{Industry}

The industrial sector includes brick production, cement, steel plants, sugar mills and powerplants. In general, emissions and activity data for these sectors are derived from available published reports and scientific literature. We then use location information from each of the facilities to develop district-wise emissions. In order to construct the gridded inventory, industrial units were geolocated precisely using the provided GPS coordinates wherever available. In general, geolocated coordinate data are available for iron and steel manufacturing, cement, sugar mills and power production. Where exact information regarding facility locations cannot be obtained directly, the district-wise distribution is a function of population density. Within the industry sector, this is the case 


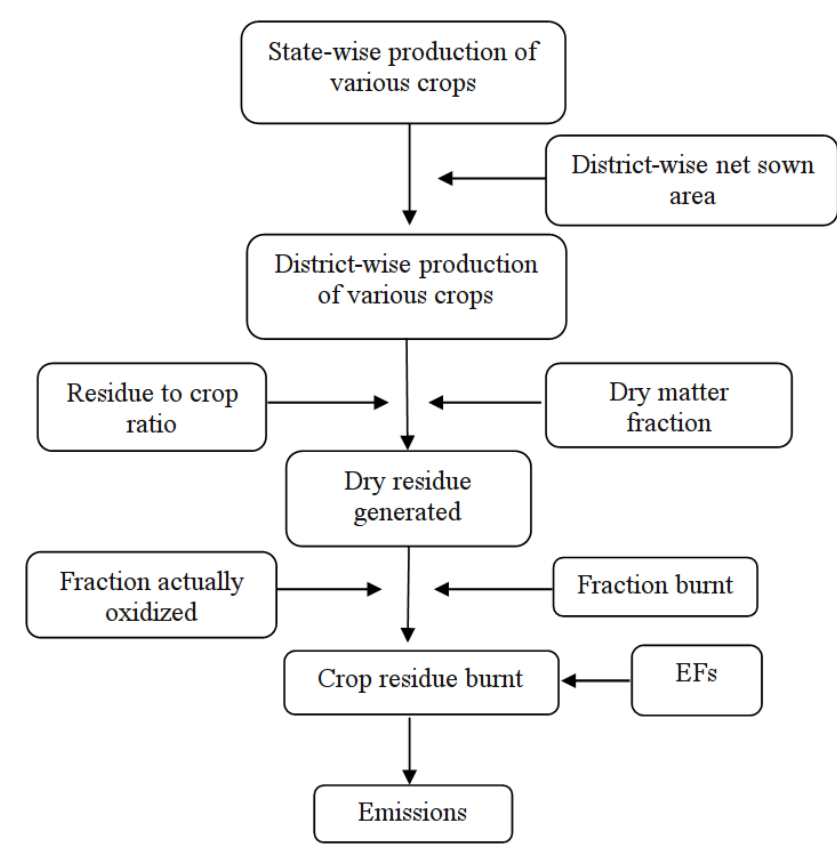

Figure 5. Flow chart for the calculation of agricultural waste burning.

for brick kilns, adding a source of uncertainty to the analysis, but also a novel emission, which previous studies have not included.

\subsubsection{Brick industry}

The Indian brick industry has more than 100000 brick kilns producing 250 billion bricks and consuming about 25 million tons of coal annually (Gupta and Narayan, 2010; Maithel et al., 2012). Bricks in India are produced locally in small enterprises on a rural scale (Rajarathnam et al., 2014). It is a seasonal industry operating predominantly from October to June (Maithel et al., 2012). Brick kilns can be classified into two major categories based upon firing practice: intermittent and continuous kilns. Intermittent kilns include clamp, scove, scotch and downdraft kilns (DDK). In these kilns bricks are fired in batches. In continuous kilns brick heating and cooling takes place simultaneously in different parts of the kiln. Several types of kilns, including the Bull trench kiln (BTK), Hoffmann kiln, zigzag kiln, tunnel kiln and vertical shaft brick kiln (Heierli and Maithel, 2015), operate continuously.

In India a majority of the bricks are produced from fixedchimney Bull trench kilns (FCBTKs) and clamps (Rajarathnam et al., 2014). There are around 60000 small-scale clamp kilns in India. Located all over India - mostly near or in villages and using biomass, coal and lignite as fuel (Rajarathnam et al., 2014) - these represent an important source of BC emissions. No account of their location, production, fuel consumption and emission factors have been published. For this study, emissions only from FCBTKs are used, which account for $70 \%$ of the total bricks produced from India, and these kilns use coal as the primary fuel (Weyant et al., 2014). The state-wise brick production (in $\mathrm{kg}$ ) through these kilns was compiled from consultation with industry experts. It was distributed district-wise according to the population of the districts in the state. The quantity produced was assumed to be normally distributed with $50 \%$ standard deviation (Maithel et al., 2012).

\subsubsection{Cement manufacturing}

The plant-wise cement production in 2011 was taken from the Cement Manufacturers Association, Government of India (CMA, 2012). India had around 150 major cement plants in 2011, which produced 180 million tons of cement and consumed 28 million tons of coal. Cement being a transportexpensive product, plants are evenly distributed across India. Since the plant-wise coal consumption was not available, the national consumption by cement industry was taken from the same source. The fuel consumption was distributed using available location data and based on cement production in 2011 .

\subsubsection{Iron and steel production}

India produced 68.6 million tons of total finished steel in 2010-11, consuming 40 million tons of coal (Ministry of Steel, 2014). The plant-wise steel production was taken from the Press Information Bureau (2011), Government of India. The coal consumption was distributed among plants according to their level of steel production. District-wise coal consumption in steel plants was subsequently determined from the location of these plants.

\subsubsection{Sugar mills}

India ranks second globally in terms of sugar production. Significant BC emissions result from sugar mills due to the usage of bagasse as a fuel. Bagasse is the fibrous residue obtained from sugarcane juice extraction and consists of cellulose $(50 \%)$, hemicellulose $(25 \%)$ and lignin $(25 \%)$ (Ezhumalai and Thangavelu, 2010; Abhilash and Singh, 2008). India has a total of around 550 sugar mills, which produced 26.3 million tons of sugar by crushing 361 million tons of sugarcane (Indian Sugar Mills Association, ISMA, 2012; DAC, 2013). Specific geolocated data are available and were used to distribute the emissions in the gridded data set. The mill-wise sugarcane crushing capacity was taken from the Department of Food \& Public Distribution (DFPD, 2011). The total sugarcane crushed was distributed among mills according to their crushing capacity. The bagasse generated was taken as $30 \%$ of the total sugarcane crushed (Pessoa Júnior et al., 1997). 


\subsubsection{Powerplants}

The Indian Central Electricity Authority (CEA, 2012) reports the plant-wise fuel consumption for coal and diesel powerplants in India. In 2011, India had an installed capacity of $112 \mathrm{GW}$ of coal- and $1.2 \mathrm{GW}$ of diesel-based thermal powerplants. There are around 100 coal-based and 14 diesel-based major thermal powerplants located across India, with location data available from government reports. District-wise fuel consumption was estimated by the location of these plants using the data contained in the report.

\subsection{Transport}

From the transportation sector emissions from road vehicles, railways, shipping and aviation have been accounted for individually. For road vehicles, to prepare gridded data from district level emissions, road network data from OpenstreetMap $^{\circledR}$ (OpenStreetMap, 2016) were utilized. The data provide a high-resolution road network in vector format. The district shapefile, grid polygons and road network shapefile were resampled to a $40 \times 40 \mathrm{~km}^{2}$ grid by calculating the total road length in each portion of the districts within a grid element and attributing that portion of the emissions to the grid. For non-road vehicles, the methodology discussed in Sect. 2 was used.

\subsubsection{Road vehicles}

Road vehicles have been divided into seven categories: two wheelers, cars, light motor vehicles (LMVs), light commercial vehicles (LCVs), taxies, trucks, buses, tractors and trailers.

The state-wise number of registered vehicles in the aforementioned categories was taken from the Ministry of Road Transport and Highways (2011). The vehicles were distributed among districts of that state according to the population of that district. In determining the emissions for 2011, we needed an estimate of the number of vehicles on the road for that year. The reported number of registered vehicles represents the cumulative number of first registrations (Parikh and Radhakrishna, 2005). In India, vehicles are neither deregistered when they are no longer in use nor are double registrations deducted. The actual number of vehicles on the road is significantly smaller than the number of registered vehicles. Baidya and Borken-Kleefeld (2009) determined the rolling fleet in 2005 using survival functions. The categorywise number of vehicles on the road as a fraction of registered vehicles was taken from Baidya and Borken-Kleefeld (2009). Emissions from the road were estimated using the number of vehicles on the road and the annual distance traveled per vehicle type.

$\mathrm{EV}_{\text {district }}=\sum_{i=1}^{n}\left(N_{i} \cdot \mathrm{AKT}_{i} \cdot \mathrm{EF}_{i}\right)$, where $\mathrm{EV}$ is the total $\mathrm{BC}$ emissions from vehicles for a district ( $\mathrm{g} \mathrm{district}^{-1}$ year $^{-1}$ ), $i$ is type of vehicle, $N$ is the number of vehicles, AKT is the annual kilometer traveled for the vehicle type $\left(\mathrm{km}_{\mathrm{year}}{ }^{-1}\right)$ and EF is the vehicle type emission factor $\left(\mathrm{g} \mathrm{km}^{-1}\right)$.

The annual average distance traveled is difficult to quantify and is a source of uncertainty in the emissions. The annual distance traveled by various vehicle types was derived from seven different studies (Table 1). This provided us with multiple estimates of the total distance traveled by a vehicle type in a year. For some vehicle types only few BC EFs were available. To compensate for lack of information, EFs were derived from $\mathrm{PM}_{2.5}$ emission factors using the $\mathrm{BC} / \mathrm{PM}_{2.5}$ fraction given by Chow et al. (2011).

\subsubsection{Railways}

Railways in India are primarily powered by electricity and diesel. The use of coal has decreased over the years and is negligible now. The annual report (2010-11) of Indian railways details the consumption of diesel and coal (Ministry of Railways, 2012b). The state-wise allocation of fuel consumed was performed according to the railway track length in the state (Ministry of Railways, 2012a) and finally districtwise according to the population of the district.

\subsubsection{Shipping}

The Ministry of Petroleum and Natural Gas (MoPNG) reports the total consumption of fuel oil (FO), high-speed diesel oil (HSDO) and light diesel oil (LDO) by the shipping subsector in 2011 (MoPNG, 2014). According to IPCC guidelines (IPCC, 2006), the fuel used in international bunkers is not counted in the national emission inventory and their estimate is recorded separately. The proportion of shipping fuel used domestically was assumed from the European Environment Agency (EEA, 2013). Due to the nonavailability of a spatial proxy, the emissions from ships have not been distributed district-wise and have only been accounted for in the national emissions.

\subsubsection{Aviation}

The total aviation turbine fuel (ATF) consumption in India was taken from MoPNG (2014). Domestic operations account for $38 \%$ of the total fuel consumption (ICAO, 2010). Domestic fuel consumption was divided into that used for landing and takeoff (LTO) and for cruise operations. The Directorate General of Civil Aviation (DGCA) reports the total number of domestic scheduled and nonscheduled aircraft departures in 2011 (DGCA, 2013). The fuel consumption per LTO was taken from IPCC (2006). The LTO ATF consumption was distributed district-wise according to the number of flights landing and taking off from the airports in that district. The cruise emission was not distributed and was only counted in national emissions. 


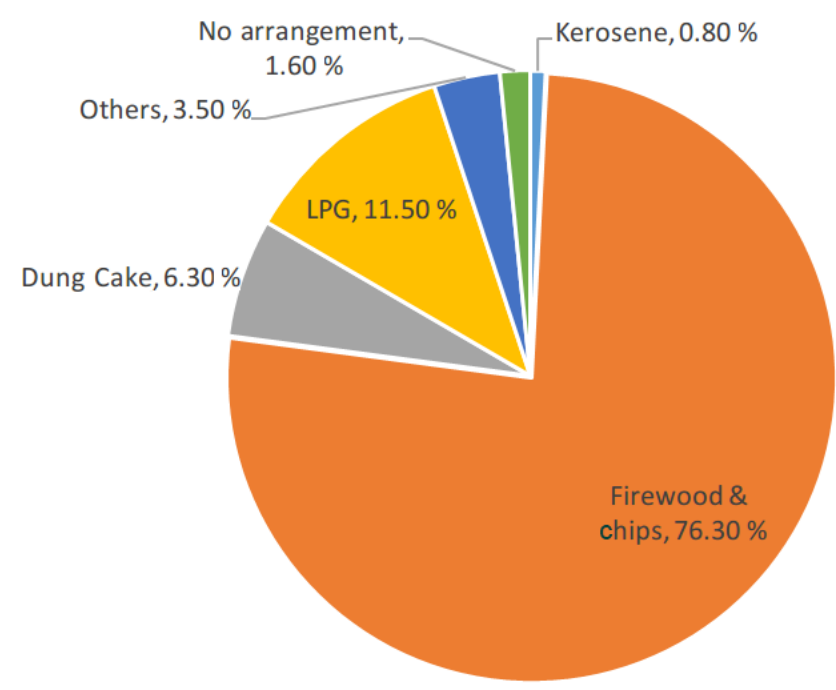

Figure 6. Energy sources used for cooking in rural India, 2009_ 2010 .

\subsection{Domestic fuel}

The domestic fuel sector includes emissions from firewood, agricultural residue, coal, liquid petroleum gas (LPG), kerosene (cooking and lighting) and dung cake.

India faces a crucial challenge of providing clean and affordable energy sources to its rural households, especially in the cooking sector. Eighty-five percent of the rural households are still dependent upon traditional biomass fuel for their cooking needs (MoSPI, 2014b). Figure 6 shows the distribution of rural households on the basis of the energy source used for cooking (MoSPI, 2014b).

The stoves used for cooking are inefficient, causing incomplete combustion and hence releasing more $\mathrm{BC}$ than would result from efficient combustion. In the year 2000, domestic fuels contributed $64 \%$ to the total BC emissions in Asia (Streets et al., 2003). State-wise per capita consumption (rural and urban) of firewood, LPG and coal was taken from a National Sample Survey (MoSPI, 2014b), which releases a report of household consumption of various commodities using a large sample of households every 5 years. Apart from this, Yevich (2003) report the state-wise total consumption of firewood, agriculture residue and dung cake in 1985. We extrapolated the fuel consumption data to 2011 by using the growth rate of rural population from 1985-1991 and the change in the number of households using these fuels for cooking from 1991 to 2011. Smith et al. (2000) also report the state-wise consumption of firewood, dung cake and agricultural residue in 1991. We extrapolated the data to 2011 using the change in number of households using these fuels for cooking from 1991 to 2011. Using data from MoSPI (2014b), Yevich (2003) and Smith et al. (2000), three estimates of domestic fuels consumed in 2011 were prepared and used within the uncertainty analysis.
According to the World Bank (2010), $25 \%$ of the Indian population does not have access to electricity. As a result kerosene-fueled lamps are the only source of lighting after sunset for a large part of the population. In 2011, over a billion liters of kerosene was consumed to fuel these lamps (MoSPI, 2014b). The information on kerosene consumed was available from two sources: MoSPI (2014b) and Lam et al. (2012). The National Sample Survey (MoSPI, 2014b) reports the state-wise per capita (rural and urban) kerosene consumption. The proportion of kerosene used for cooking versus lighting in India was taken from Lam et al. (2012). Another estimate of kerosene consumed in lamps was derived following the methodology described in Lam et al. (2012).

\subsection{Other}

The sector "other" incorporates emissions from the use of diesel in power generation sets. One of the largest consumers of diesel are irrigation pumps. In addition, diesel is used in power generation for mobile towers, private households, small industry and commercial enterprises.

\subsubsection{Irrigation pumps}

Agriculture is a core economic activity of India, with about $60 \%$ of the population involved in the activity. In 2011 India used around 2.4 billion liters of diesel for irrigation pumps (MoPNG, 2013). The use of dug wells and tube wells is very common for irrigation purposes in India. Diesel powered pumps are used for mini irrigation schemes in farms with minimal or no access to electricity. The diesel consumed was distributed district-wise according to the net sown area in that district (Ministry of Agriculture, 2011).

\subsubsection{Diesel generator sets}

In 2011-12, India faced an overall power deficit of $8.5 \%$ and peak power shortage of $10.6 \%$ (CEA-LGBR, 2013). To deal with this deficit, there were prolonged power cuts throughout the country especially during the peak consumption period. Increasingly, private households, commercial enterprises and industries are using diesel generators to maintain consistent power supply during power outages. Although there is no official estimate of the amount of diesel consumed by diesel generators, ICF International estimates that 4.51 billion liters of diesel was used in the year 2012-13 (Shakti Sustainable Energy Foundation, 2014). The growth rate of the power deficit in India was used to adjust this value for 2011 (CEALGBR, 2013). The telecom industry is one of the largest users of diesel generators. In 2011, India had more than half a million cell towers (Press Information Bureau, 2011). Most of these towers are located in villages where grid-connected electricity is not available. They use small generators fueled by diesel for their power needs. The total diesel consumption by cell towers was taken from MoPNG (2013). The fuel con- 

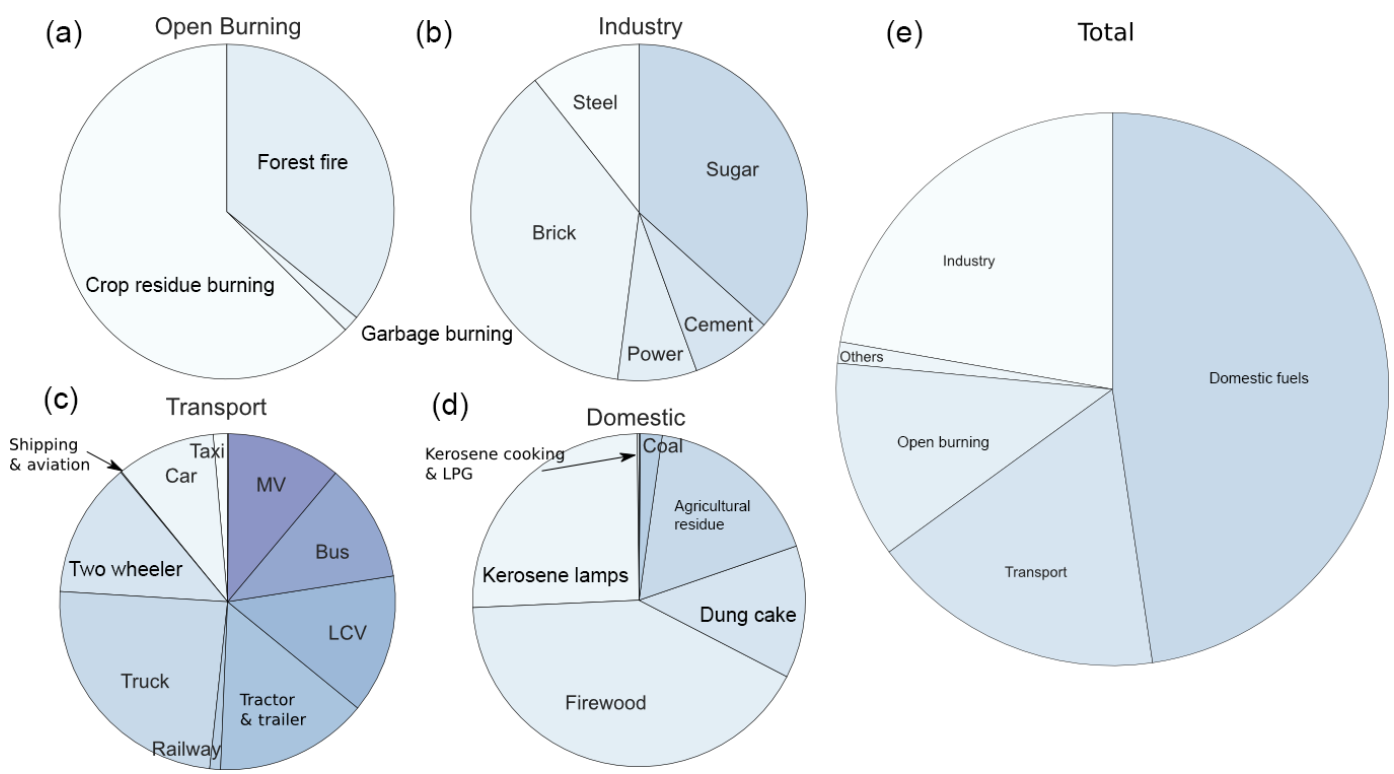

Figure 7. (a-d) Proportion of subcategories to the major sector emissions and (e) contribution of major sector emissions to the national emissions total.

sumed was distributed state-wise according to the number of mobile towers in that state. It was then distributed districtwise according to the population of the district. Diesel consumed by generators in mobile towers was deducted from the total amount of 4.51 billion liters consumed by diesel generators to estimate the remaining amount. Due to the paucity of data it was not possible to spatially distribute the remaining emissions to grids, so they have only been accounted for in the total national emissions.

\section{Results and discussion}

Tables 1 and 2 present the probabilistic best-fit distributions, mean and standard deviation for activity data and EFs for sources considered in this study. The mean district level activity data and EFs were used to estimate the district-wise emissions. It may be noted that kerosene lamps have the highest EF among all sources considered in this study; these lamps convert $8.5 \%$ of the fuel directly into BC. In the openburning sector, forest fires have the highest EF. In the industry sector, EF is highest for the sugar industry, as the industry uses bagasse as a fuel in a very inefficient combustion process. For the transport sector, EFs for diesel-operated vehicles (railways, ships, bus, truck, tractor and trailer, LCV) are higher than that for gasoline-operated vehicles (two wheeler, LMV, car).

Total BC emissions for the year 2011 have been estimated to be $901 \pm 152 \mathrm{Gg}$ (Table 3), of which $47 \%$ (425 Gg) originated from domestic fuel consumption, $22 \%(198 \mathrm{Gg})$ from industry, $17 \%(154 \mathrm{Gg})$ from the transport sector and $12 \%$ $(103 \mathrm{Gg})$ from open burning. Diesel use in mobile towers and irrigation pumps contributed $2 \%(20 \mathrm{Gg})$ to total BC emissions (Fig. 7). Firewood with emissions of $177 \mathrm{Gg}$ is the single most emitting source. It emits more than transportation $(154 \mathrm{Gg})$ and open-burning $(103 \mathrm{Gg})$ categories. As shown in Fig. 6, $76.3 \%$ of the 140 million rural households MoSPI (2014b) use firewood as the primary source of energy for cooking.

The spatial distribution of national emissions is presented in Fig. 8. From the map it can be easily concluded that the Indo-Gangetic Plain (IGP) is the main contributor to national $\mathrm{BC}$ emissions. This can be attributed to the very high population density and presence of major BC emitting industries like sugar and brick production in this region. Some of the states in the IGP are among the least developed in India, with little access to even basic amenities like electricity, clean cooking fuels, sanitation, health care, etc. More than $90 \%$ of the rural households in Uttar Pradesh and Bihar use biomass fuels as their primary source of cooking, and more than $65 \%$ are dependent upon kerosene lamps as their primary source of lighting (NSSO, 2015). The high dependence on biomass fuels and the presence of brick and sugar industry accentuates the emissions from this region. With annual emissions of $140 \mathrm{Gg}$, the state of Uttar Pradesh emits the most in the IGP followed by West Bengal $(57.67 \mathrm{Gg})$, Bihar $(47.8 \mathrm{Gg})$, Punjab $(34.01 \mathrm{Gg})$, Haryana $(26.82 \mathrm{Gg})$ and the National Capital Territory (NCT) of Delhi $(6.74 \mathrm{Gg})$. The major emissions sources in Uttar Pradesh are kerosene lamps (12\%), biomass cooking fuels (30\%), brick kilns (20\%) and sugar mills $(17 \%)$. High emissions from IGP and its vicinity to the Himalayas potentially pose a serious threat to water security in the region, resulting from impacts on the cryosphere from $\mathrm{BC}$ deposition and atmospheric heating. 

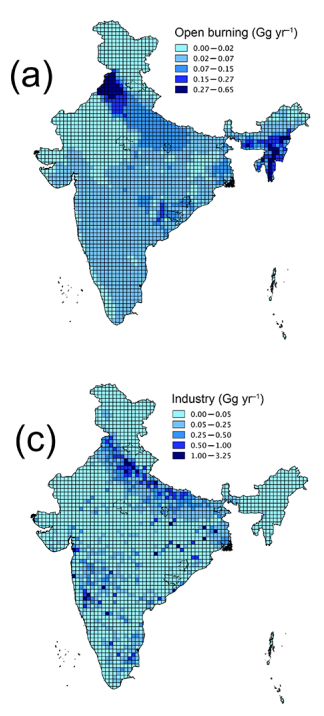
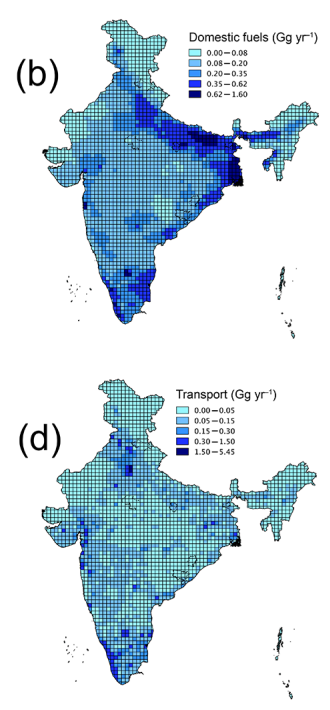

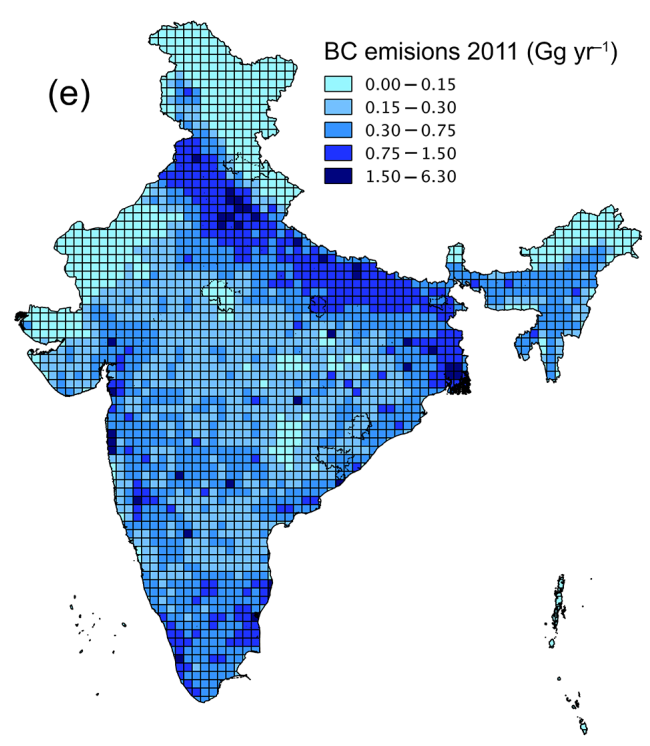

Figure 8. (a-d) Maps of major sector emissions and (e) spatial variability of national emissions total for BC.

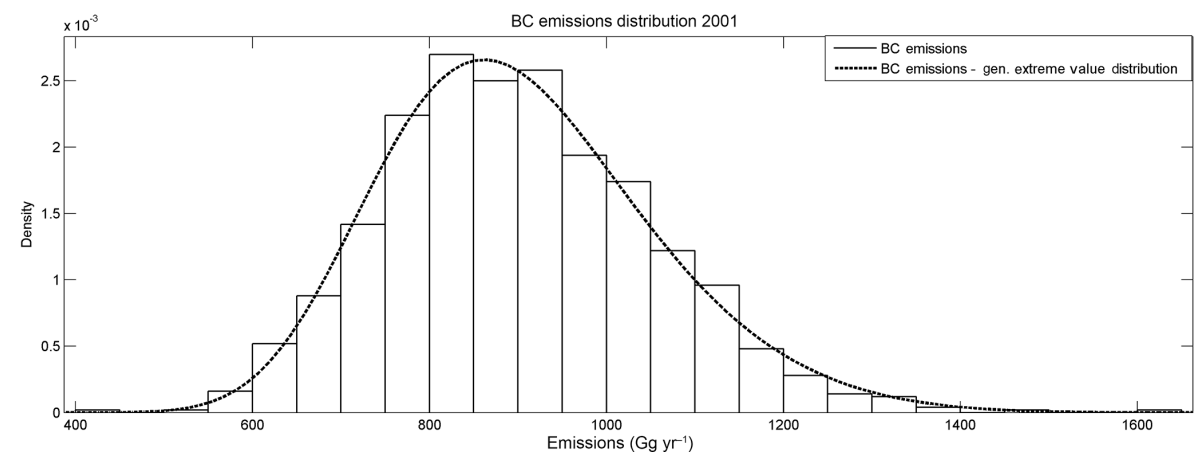

Figure 9. Gen. extreme value distribution fit for the national BC emissions.

As discussed in Sect. 2, best-fit probabilistic distributions were obtained for EF and activity data (for each source) using the KS statistic. A sample of 1000 numbers was generated from each of the two distributions (EF and activity data), the product of which provides over 1 million emission points. The mean and standard deviation were determined for each source using the obtained emission points. The emission points were added up for all the sources to get, overall, 1000 national emission points and, subsequently, the national mean emission and standard deviation. A best-fit probabilistic distribution curve was obtained for the national emission points on the basis of the KS statistic. The probabilistic distribution for overall national emissions was found to be a general extreme value distribution with KS statistics of 0.01 (Fig. 9). Figure 10 presents the sector-wise optimally fit distributions for the $\mathrm{BC}$ emissions.

\subsection{Open burning}

The national level emissions from this sector contribute $12 \%$ $(103 \mathrm{Gg})$ to the total emissions. Burning of crop residue has been the major contributor $(62 \%)$, followed by forest fires (36\%). MSW burning contributed only $2 \%$ to the openburning emissions. The source-wise emission contribution and spatially distributed open-burning emissions are presented in Figs. 7 and 8. The emissions from open burning are highest from the northwest states of Punjab and Haryana (crop residue burning) and the northeastern states of Nagaland, Manipur, Mizoram and Tripura (forest fires). Punjab and Haryana are the main food-producing states of India. In April, May, October and November, the crop residue is burnt to clear the land for the next crop. In the northeast, openburning emissions arise primarily from forest fires; however, some tribal communities also practice slash and burn agriculture in this region as well. 


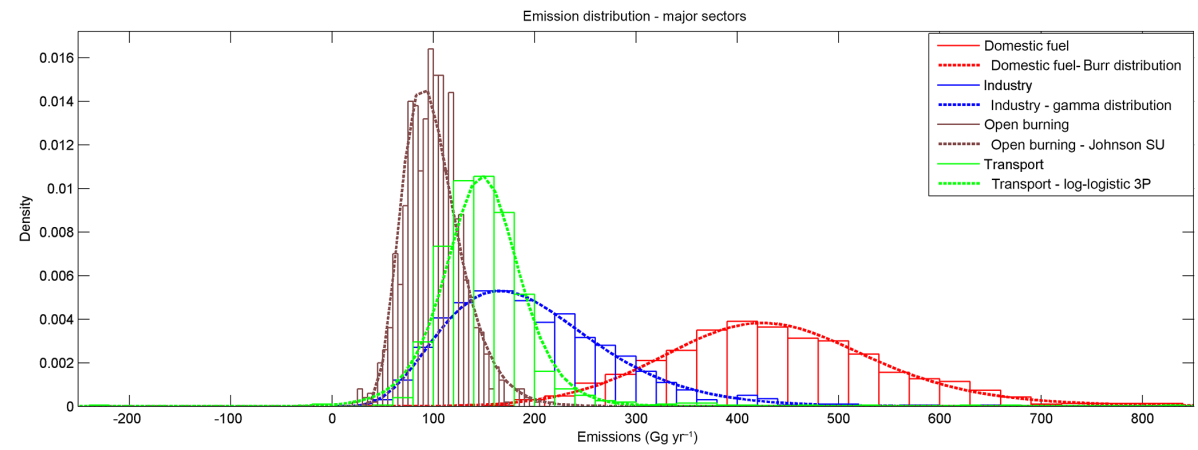

Figure 10. Sectorial emission histograms and associated best-fit PDFs.

\subsection{Industry}

National level industry sector emissions account for $22 \%$ $(198 \mathrm{Gg})$ of the total emissions. In this sector, brick and sugar production contribute the maximum emissions (37\% each), followed by steel production (11\%), cement (8\%) and powerplants (7\%) (Fig. 7). Spatially distributed emissions from the industry sector are presented in Fig. 8. The hotspots of industrial emissions are the states in the IGP, as most of the brick and sugar industries lie in this area. It is also evident and expected from Fig. 8 that metropolitan cities contribute significantly to the sector as they have major industrial belts on the periphery. High emissions from the brick and sugar industry result from the use of low-grade fuels and from dated and inefficient systems and processes. While powerplants account for $75 \%$ of coal consumption, their BC emissions are just $7 \%$ of the total industrial emissions, due to the higher efficiency of combustion in these systems. An acknowledged source of uncertainty in our approach is the lack of specific geolocated coordinate data for the two largest emission sources, brick and sugar.

\subsection{Transport}

Transportation sector emissions account for $17 \%(154 \mathrm{Gg})$ of the national BC emissions in 2011. In the transport sector trucks have been found to emit the most (24\%), followed by tractor and trailers (15\%). Emissions from bus, car, LCV, LMV and two wheelers contributed 12, 10, 13, 11 and $13 \%$ to national transport sector $\mathrm{BC}$ emissions, respectively. Railways contributed $0.2 \%$ to $\mathrm{BC}$ emissions in 2011; shipping and aviation combined emitted less than $0.05 \%$ (Fig. 7). The spatial distribution of transportation emissions is presented in Fig. 8. The main contributors are the metropolitan cities, the NCT of Delhi, Mumbai and Bangalore. The results also indicated that the majority of the emissions from the transport sector originate from diesel road vehicles (truck, tractors and trailers, bus, LCV and LMV).

\subsection{Domestic fuel}

Domestic fuels account for almost half of the national BC emissions $(47 \%, 425 \mathrm{Gg})$. Within the sector, firewood contributes most significantly, (42\%), followed by kerosene lamps (26\%). Agricultural residue, dung cake and coal used for cooking contributed 17, 13 and $2 \%$, respectively (Fig. 7). Figure 8 shows the spatially distributed emissions of domestic fuel usage. Here also, the majority of emissions arise from the IGP due to the high population density in this area. Also, the poverty levels are high in this region, so a larger proportion of the population tends to use cheaper biofuels for cooking. The biofuel used in handmade stoves has low combustion temperatures leading to an inefficient combustion process, and consequently the domestic fuel sector has higher $\mathrm{BC}$ emissions. Also, these are uncontrolled emission sources. Kerosene lamps $(109 \mathrm{Gg})$ are the second-highest emitting source as a result of the very high EF of kerosene lamps. While the emissions from kerosene lamps are more than the entire open-burning sector combined, studies must be conducted to evaluate the potential impact and transport of this source of BC. It likely has extremely significant health impacts due to the emissions being contained within homes, but the climate impact is likely as large as for open burning.

\subsection{Other}

Emissions from this category account for slightly more than $2 \%(20 \mathrm{Gg})$ of the national BC emissions. Within this category emissions from use of diesel in irrigation pumps contribute $8 \mathrm{Gg}$, and its use in mobile generators contributes $12 \mathrm{Gg}$. Among diesel generators, their use in mobile towers contributes $4 \mathrm{Gg}$ and other applications (private households, small commercial enterprises and industry) account for the remaining $8 \mathrm{Gg}$.

\subsection{Uncertainty analysis}

Figure 11 shows the mean and standard deviations based on best-fit probabilistic distributions of emissions from the major sectors. Based on the Monte Carlo simulations using the 


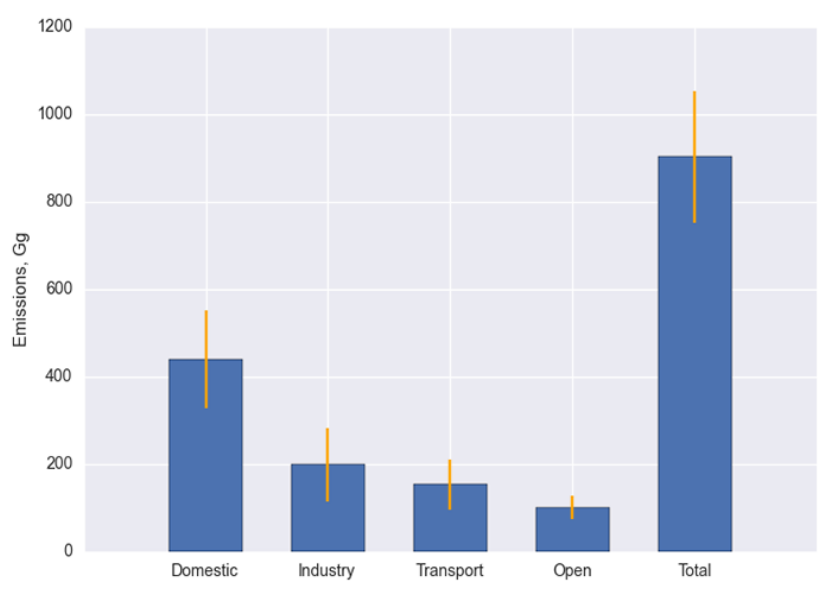

Figure 11. Mean and standard deviation for each of the major sectors of emissions for India, 2011.

multiple emissions estimates and available information on uncertainty, the PDFs for each of the sectors is calculated as shown in Fig. 10. The best-fit distribution for the domestic fuels sector was found to be a Burr distribution with a KS statistic of 0.01 ; for industrial emissions, it was a gamma distribution with KS statistics of 0.02; for open-burning emissions, it was a Johnson SU distribution with a KS statistic of 0.02 ; and it was log-logistic (3P) for the transport sector, with a KS statistic of 0.03 . The uncertainty is highest for emissions from the domestic fuels sector. The EFs and activity data for the sources in the domestic fuel sector show a large variation leading to high uncertainty in the $\mathrm{BC}$ emissions as there is no accurate database of the population using cookstoves, of the quantity of fuel consumed and the stoves' efficiency.

\subsection{Comparison with prior estimates}

Emissions in this study have been determined using a Monte Carlo simulation of multiple activity data and emission factors. As previous studies have used point estimates for these highly uncertain quantities, the results are bound to differ. Figure 12 presents the comparison of the results of this study (Table 3) with emission inventories developed in the past. For the base year 2011, the estimate is about $80 \%$ of that reported in the SAFAR emission inventory $\left(1119 \mathrm{Gg} \mathrm{yr}^{-1}\right)$. For inventories with base year 2010, total national emissions estimated in this study are a factor of 1.3 higher than RETRO $\left(697 \mathrm{Gg} \mathrm{yr}^{-1}\right)$, factor of 0.8 of that estimated in Klimont et al. (2009) (1104 $\left.\mathrm{Gg} \mathrm{yr}^{-1}\right)$, a factor of 0.9 of that estimated in $\mathrm{Lu}$ et al. (2011) (1015 $\left.\mathrm{Gg} \mathrm{yr}^{-1}\right)$, and they were in agreement with emissions determined by Ohara et al. (2007) (862 $\left.\mathrm{Gg} \mathrm{yr}^{-1}\right)$. All prior national emission estimates lie within 2 standard deviations of our mean estimate.

Emissions estimates from the domestic fuels sector $\left(425 \pm 112 \mathrm{Gg} \mathrm{yr}^{-1}\right)$ are lower by a factor of $0.7-0.9$ than Pandey et al. (2014) (488 Gg yr ${ }^{-1}$ ), Klimont et al. (2009)
Table 3. Mean national emissions and standard deviation.

\begin{tabular}{|c|c|}
\hline Sector/subsector & Emissions $\left(\mathrm{Gg} \mathrm{yr}^{-1}\right)$ \\
\hline Open burning & $102.84 \pm 27.56$ \\
\hline Crop residue burning & $64.31 \pm 17.19$ \\
\hline Forest fire & $36.90 \pm 12.85$ \\
\hline Garbage burning & $1.63 \pm 0.62$ \\
\hline Industry & $198.5 \pm 83.391$ \\
\hline Brick & $74.11 \pm 61.38$ \\
\hline Steel & $21.09 \pm 32.18$ \\
\hline Sugar & $72.76 \pm 25.05$ \\
\hline Cement & $15.45 \pm 22.26$ \\
\hline Power & $15.09 \pm 23.88$ \\
\hline Transport & $154.34 \pm 56.14$ \\
\hline Bus & $17.64 \pm 8.72$ \\
\hline Car & $14.69 \pm 10.54$ \\
\hline LMV & $17.01 \pm 25.03$ \\
\hline $\mathrm{LCV}$ & $20.62 \pm 10.51$ \\
\hline Truck & $37.46 \pm 20.49$ \\
\hline Taxi & $2.13 \pm 1.44$ \\
\hline Two wheeler & $20.11 \pm 39.50$ \\
\hline Tractor and trailer & $22.79 \pm 11.41$ \\
\hline Railway & $1.60 \pm 1.32$ \\
\hline Shipping & $0.15 \pm 0.07$ \\
\hline Aviation & $0.14 \pm 0.04$ \\
\hline Domestic fuel & $425.36 \pm 111.97$ \\
\hline Dung cake & $54.79 \pm 48.15$ \\
\hline Agriculture residue & $74.38 \pm 44.17$ \\
\hline Firewood & $177.34 \pm 83.88$ \\
\hline Coal & $9.02 \pm 14.622$ \\
\hline Kerosene cooking & $0.83 \pm 0.19352$ \\
\hline LPG & $0.47 \pm 0.39$ \\
\hline Kerosene lamps & $108.53 \pm 27.10$ \\
\hline Others & $20.08 \pm 2.59$ \\
\hline Irrigation pumps & $7.55 \pm 1.73$ \\
\hline Diesel generators (mobile towers) & $4.14 \pm 0.85$ \\
\hline Diesel generators (other) & $8.39 \pm 1.73$ \\
\hline Total & $901.11 \pm 151.56$ \\
\hline
\end{tabular}

$\left(628 \mathrm{Gg} \mathrm{yr}^{-1}\right)$ and $\mathrm{Lu}$ et al. (2011) $\left(579 \mathrm{Gg} \mathrm{yr}^{-1}\right)$. For the transport sector our emission estimate $\left(154 \pm 56 \mathrm{Gg} \mathrm{yr}^{-1}\right)$ is almost identical to that presented in Sadavarte and Venkataraman (2014) (144 $\left.\mathrm{Gg} \mathrm{yr}^{-1}\right)$ and a factor of 1.11.3 higher than the emissions determined by $\mathrm{Lu}$ et al. (2011) (111 Gg yr${ }^{-1}$ ), Baidya and Borken-Kleefeld (2009) (123 $\mathrm{Gg} \mathrm{yr}^{-1}$ ) and Klimont et al. (2009) (136 $\left.\mathrm{Gg} \mathrm{yr}^{-1}\right)$. In the industry sector our emissions $(198 \pm 83 \mathrm{Gg})$ are $10-20 \%$ lower in view of the inclusion of only higher emitting industries in this study. The combined industrial emission estimate of Sadavarte and Venkataraman (2014) (formal industry) and Pandey et al. (2014) (informal industry) $\left(212 \mathrm{Gg} \mathrm{yr}^{-1}\right)$ is in 


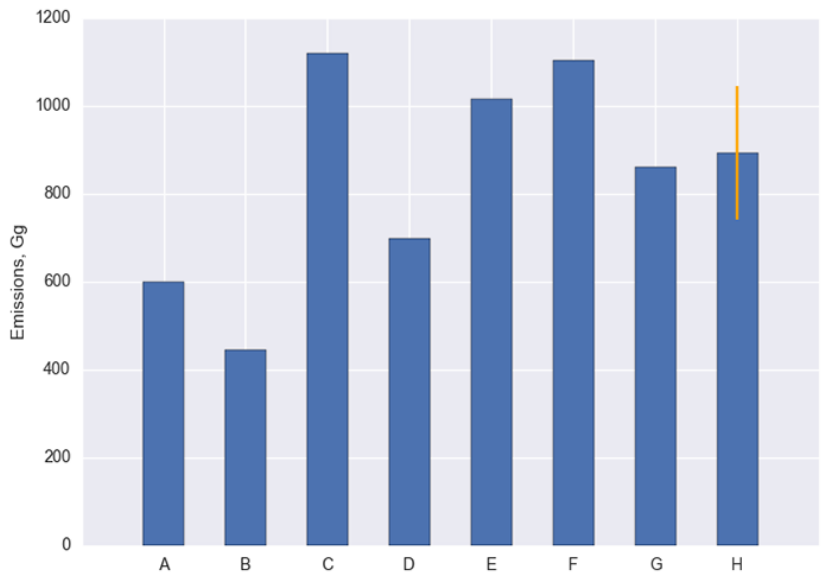

Figure 12. Comparison of current $\mathrm{BC}$ emissions estimate with previously published results for India. A: Streets et al. (2003) (base year 2000); B: Reddy and Venkataraman (2002a, 2002b) (base year 1997); C: Sahu et al. (2008) (base year 2011); D: Schultz et al. (2008) (base year 2010); E: Lu et al. (2011) (base year 2010); F: Klimont et al. (2009) (base year 2010); G: Ohara et al. (2007) (base year 2010); H: this study (base year 2011).

good agreement with our emission estimate (factor 0.94). Estimated industrial emissions are a factor of $0.8-0.9$ lower than Lu et al. (2011) (227 $\mathrm{Gg} \mathrm{yr}^{-1}$ ) and Klimont et al. (2009) $\left(261 \mathrm{Gg} \mathrm{yr}^{-1}\right)$. Emissions from open crop residue burning $\left(64 \pm 17 \mathrm{Gg} \mathrm{yr}^{-1}\right)$ are in close agreement (factor 0.8-1) with Jain (2014) $\left(68 \mathrm{Gg} \mathrm{yr}^{-1}\right)$, Lu et al. (2011) $\left(74 \mathrm{Gg} \mathrm{yr}^{-1}\right)$ and Pandey et al. (2014) $\left(80 \mathrm{Gg} \mathrm{yr}^{-1}\right)$. Forest fire emissions $(37 \pm 13 \mathrm{Gg})$ are almost identical to those determined in Reddy and Venkataraman (2002a) $\left(39 \mathrm{Gg} \mathrm{yr}^{-1}\right)$. As with the national emission estimate, for all sectors prior emission estimates are within 1 or 2 standard deviations from our mean emission estimate.

\subsection{Fuel balance}

A fuel balance approach has been used to ensure that no major emission source has been overlooked in our study. Since biomass consumption data in India are highly uncertain, this approach was only employed for emissions arising from combustion of fossil fuels. Emissions from combustion of diesel, gasoline, fuel oil, ATF, LDO and coal were estimated using emission factors from Streets et al. (2003) and Bond et al. (2004). In 2011, emission from these fuels was estimated to be $281 \mathrm{Gg}$ (Table 4). This was very close to emissions estimated from our methodology ( $304 \mathrm{Gg}$ ), considering the emission sources which use these fuels as a combustion source.

\subsection{Seasonality of emissions}

There is a strong seasonality associated with $\mathrm{BC}$ emissions in India. Crop residue burning, forest fires, and the brick
Table 4. Fuel balance.

\begin{tabular}{llll}
\hline Sector/fuel & $\begin{array}{l}\text { Activity } \\
(\mathrm{Mt})\end{array}$ & $\begin{array}{l}\mathrm{EF} \\
\left(\mathrm{g} \mathrm{kg}^{-1}\right)\end{array}$ & $\begin{array}{l}\text { Emission } \\
(\mathrm{Gg})\end{array}$ \\
\hline Coal & $535.88^{1}$ & $0.328^{2}$ & 175.77 \\
Gasoline/petrol & $14.442^{3}$ & $2.795^{4}$ & 40.37 \\
Diesel & $63.504^{3}$ & $1.02^{4}$ & 64.77 \\
Fuel oil & $6.624^{3}$ & $0.04^{4}$ & 0.26 \\
ATF & $5.324^{3}$ & $0.03^{4}$ & 0.16 \\
\hline Total & & & 281.33 \\
\hline${ }^{1}$ MoSPI (2014a). ${ }^{2}$ Streets et al. (2003). ${ }^{3}$ MoPNG (2014). ${ }^{4}$ Bond et al. \\
(2004).
\end{tabular}

and sugar industry have a seasonal dependence in emissions. Forest fires are predominant from February to July. Monthly $\mathrm{BC}$ emissions from forest fires were estimated using MODIS burnt-area data. The brick industry becomes active after the monsoon season from October to June (Maithel et al., 2012); the sugar industry operates from November to June (Tyagi, 1995), and the emissions are equally distributed among the months of operation. Burning of crop residues generally occurs in the harvesting months, which are October-November for kharif crop and April-May for rabi crop. Emissions of agricultural open burning are equally distributed among the months of April, May, October and November. For all the other sources, emission rates are assumed to be uniform throughout the year. Using these data, monthly variation of BC emissions has been estimated and is shown in Fig. 13.

The emissions in April are highest due to the burning of crop residues. Despite the absence of crop residue burning, emissions in March are also high because of the emissions from forest fires. As we have shown that a considerable amount of the emissions comes from the IGP, which is in close proximity to the Himalayas, this causes further concern regarding the potential cryospheric impact of these aerosols as they are strongest during the period when the seasonal snowmelt period is beginning and they could be incorporated into the snowpack.

\section{Conclusions}

A spatially resolved BC emission inventory for 2011 has been developed, considering major sectors and with careful consideration of subsector sources. The sources were classified into five major sectors: (i) open burning, including forest fire emissions, open solid-waste burning and agriculture residue burning; (ii) industry, including brick industry, cement, steel plants, sugar mills and powerplants; (iii) transport, including two wheelers, cars, light motor vehicles passenger, light commercial vehicles, taxies, trucks, buses, tractors and trailers, railways, shipping, and airways; (iv) domestic fuel, including firewood burning, agricultural residue, coal, liquid petroleum gas, kerosene (cooking and lighting) 


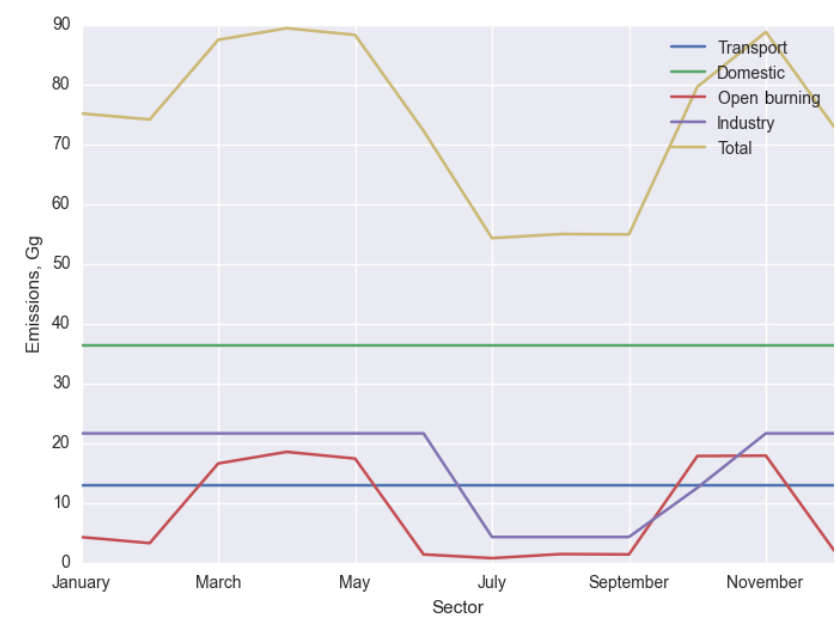

Figure 13. Time series of monthly emissions for India, 2011. Note the strong seasonality of the open-burning and industry sector. In the latter case, the seasonality results predominately from sugarcane production.

and dung cake; and (v) "other", including use of diesel in irrigation pumps and for other power generation in diesel generators.

This is a first-of-its-kind comprehensive study which included sources such as kerosene lamps and forest fires that were not part of earlier emission inventories. Furthermore, for each sector, source uncertainties in emissions have been estimated based on variability in available activity data and emission factors. Lastly, and significantly, we provide our estimate of emissions at a monthly temporal resolution on a spatially distributed $40 \times 40 \mathrm{~km}$. grid.

The national BC emissions for India in 2011 are estimated to be $901 \pm 152 \mathrm{Gg} \mathrm{yr}^{-1}$, with domestic fuels contributing the most $(47 \%)$, followed by industries $(22 \%)$, transport $(17 \%)$, open burning $(12 \%)$ and others $(2 \%)$. Large emission in the domestic fuels sector stems from the extensive use of biomass for cooking in India. Firewood is the single largest emitter, with $177 \mathrm{Gg}(20 \%)$ of $\mathrm{BC}$ emissions in 2011. The emissions from firewood are more than the entire transportation sector combined. Kerosene lamps surprisingly contribute $12 \%$ to the national $\mathrm{BC}$ emissions. The emissions have been found to be have a significant seasonality, varying from $55 \mathrm{Gg}$ in July to $90 \mathrm{Gg}$ in April 2011.

The results of the study could be used to assess the contribution of different sources to national and regional emissions. The spatial resolution of the inventory should be useful for modeling the black carbon processes in the atmosphere through air quality models. Monthly gridded emission data sets can also be prepared for finer temporal-resolution input. To improve the future $\mathrm{BC}$ emission estimates, local emission factors and activity data should be improved, especially for domestic fuels and the brick industry. The emission inventory can be improved nationally, regionally and temporally by comparing the modeled emission estimates (providing the inventory as input to air quality models) with the observed data.

\section{Data availability}

The inventory is available from the authors on request. More information may be found at http://www.mn.uio.no/ geo/english/research/projects/hycamp.

Acknowledgement. This work was conducted within the Norwegian Research Council's INDNOR: Hydrologic sensitivity to Cryosphere-Aerosol interaction in Mountain Processes (HyCAMP) (Researcher project - MILJØ2015 no. 222195) and The Department of Science and Technology, Government of India, through Grant no. INT/NOR/RCN/P-05/2013. We are grateful for constructive feedback received from two anonymous reviewers and our editor, who encouraged the addition of the road network and incorporating the fuel balance analysis.

Edited by: C. Hoose

Reviewed by: three anonymous referees

\section{References}

Abhilash, P. C. and Singh, N.: Influence of the application of sugarcane bagasse on lindane $(\gamma-\mathrm{HCH})$ mobility through soil column: Implication for biotreatment, Bioresource Technol., 99, 89618966, doi:10.1016/j.biortech.2008.05.006, 2008.

Akagi, S. K., Yokelson, R. J., Wiedinmyer, C., Alvarado, M. J., Reid, J. S., Karl, T., Crounse, J. D., and Wennberg, P. O.: Emission factors for open and domestic biomass burning for use in atmospheric models, Atmos. Chem. Phys., 11, 4039-4072, doi:10.5194/acp-11-4039-2011, 2011.

Andreae, M. O. and Merlet, P.: Emission of trace gases and aerosols from biomass burning, Global Biogeochem. Cy., 15, 955-966, doi:10.1029/2000GB001382, 2001.

ARAI: Air Quality Monitoring Project-Indian Clean Air Programme (ICAP), Draft report on Emission Factor development for Indian Vehicles, Tech. rep., The Automotive Research Association of India, 2008.

Baidya, S. and Borken-Kleefeld, J.: Atmospheric emissions from road transportation in India, Energy Policy, 37, 3812-3822, doi:10.1016/j.enpol.2009.07.010, 2009.

Bond, T. C. and Sun, K.: Can reducing black carbon emissions counteract global warming?, Environ. Sci. Technol., 39, 59215926, doi:10.1021/es0480421, 2005.

Bond, T. C., David G., S., Kristen F., Y., Sibyl M., N., Jung-Hun, W., and Zbigniew, K.: A technology-based global inventory of black and organic carbon emissions from combustion, J. Geophys. Res., 109, D14203, doi:10.1029/2003JD003697, 2004.

Bond, T. C., Bhardwaj, E., Dong, R., Jogani, R., Jung, S., Roden, C., Streets, D. G., and Trautmann, N. M.: Historical emissions of black and organic carbon aerosol from energy-related combustion, 1850-2000, Global Biogeochem. Cy., 21, GB2018, doi:10.1029/2006GB002840, 2007. 
Bond, T. C., Doherty, S. J., Fahey, D. W., Forster, P. M., Berntsen, T., Deangelo, B. J., Flanner, M. G., Ghan, S., Kärcher, B., Koch, D., Kinne, S., Kondo, Y., Quinn, P. K., Sarofim, M. C., Schultz, M. G., Schulz, M., Venkataraman, C., Zhang, H., Zhang, S., Bellouin, N., Guttikunda, S. K., Hopke, P. K., Jacobson, M. Z., Kaiser, J. W., Klimont, Z., Lohmann, U., Schwarz, J. P., Shindell, D., Storelvmo, T., Warren, S. G., and Zender, C. S.: Bounding the role of black carbon in the climate system: A scientific assessment, J. Geophys. Res.-Atmos., 118, 5380-5552, doi:10.1002/jgrd.50171, 2013.

Borken, J., Steller, H., Merétei, T., and Vanhove, F.: Global and Country Inventory of Road Passenger and Freight Transportation: Fuel Consumption and Emissions of Air Pollutants in Year 2000, Transportation Research Record, 2011, 127-136, doi:10.3141/2011-14, 2008.

Bowerman, N. H. A., Frame, D. J., Huntingford, C., Lowe, J. A., Smith, S. M., and Allen, M. R.: The role of short-lived climate pollutants in meeting temperature goals, Nature Climate Change, 3, 1021-1024, doi:10.1038/nclimate2034, 2013.

Cachier, H.: Carbonaceous combustion aerosols, in: Atmospheric Particles, edited by: Harrison, R. and van Grieken, R., vol. 2, pp. 1-2, pp. 295-348, John Wiley, New York, 1998.

CEA: Annual report on fuel consumption in Power Plants, Tech. rep., Central Electricity Authority, New Delhi, available at: http: //www.cea.nic.in (last access: January 2015), 2012.

CEA-LGBR: Load generation balance report 2012-13, 2013-14, Tech. rep., Central Electricity Authority, Ministry of Power, Government of India, New Delhi, 2013.

Census of India: India: Administrative Divisions 2011, available at: http://www.censusindia.gov.in/2011census/maps/atlas/ 00part1.pdf (last access: April 2015), 2011.

Chen, Y., Sheng, G., Bi, X., Feng, Y., Mai, B., and Fu, J.: Emission factors for carbonaceous particles and polycyclic aromatic hydrocarbons from residential coal combustion in China, Environ. Sci. Technol., 39, 1861-1867, doi:10.1021/es0493650, 2005.

Chen, Y., Zhi, G., Feng, Y., Liu, D., Zhang, G., Li, J., Sheng, G., and Fu, J.: Measurements of black and organic carbon emission factors for household coal combustion in China: Implication for emission reduction, Environ. Sci. Technol., 43, 9495-9500, doi:10.1021/es9021766, 2009.

Chow, J. C., Watson, J. G., Lowenthal, D. H., Antony Chen, L. W., and Motallebi, N.: $\mathrm{PM}_{2.5}$ source profiles for black and organic carbon emission inventories, Atmos. Environ., 45, 5407-5414, doi:10.1016/j.atmosenv.2011.07.011, 2011.

CMA: Annual Report 2011-12, Tech. rep., Cement Manufacturers' Association, New Delhi, available at: http://www.cmaindia.org/ cms/images/annual-report/Annual-Report-2011-12.pdf, 2012.

Cooke, W. F., Liousse, C., Cachier, H., and Feichter, J.: Construction of Construction of a $1^{\circ} \times 1^{\circ}$ fossil fuel emission data set for carbonaceous aerosol and implementation radiative impact in the ECHAM4 model, J. Geophys. Res., 104, 22137-22162, doi:10.1029/1999JD900187, 1999.

CPCB: Management of Municipal Solid Waste, Tech. rep., Central Pollution Control Board, Government of India, New Delhi, 2007.

CPCB: Status Report on Municipal Solid Waste Management, Tech. rep., Ministry of Environment \& Forests, Government of India, New Delhi, 2012.

DAC: Annual Report 2012-13, Tech. rep., Department of Agriculture and Cooperation, Government of India, New Delhi, 2013.
DFPD: Department of Food and Public Distribution, available at: http://dfpd.nic.in/ (last access: January 2015), 2011.

DGCA: Air Transport Statistics 2011-12 \& 2012-13, Tech. rep., Directorate General of Civil Aviation, Government of India, New Delhi, 2013.

EEA: The impact of international shipping on European air quality and climate forcing, Tech. Rep. 4, European Environment Agency, doi:10.2800/75763, 2013.

Ezhumalai, S. and Thangavelu, V.: Kinetic and optimization studies on the bioconversion of lignocellulosic material into ethanol, BioResources, 5, 1879-1894, 2010.

Flanner, M. G., Zender, C. S., Randerson, J. T., and Rasch, P. J.: Present-day climate forcing and response from black carbon in snow, J. Geophys. Res.-Atmos., 112, D11202, doi:10.1029/2006JD008003, 2007.

FSI: State of Forest Report 2013, Tech. rep., Forest Survey of India, Ministry of Environment \& Forests, Government of India, New Delhi, 2013.

FSI: Forest Fire Search - Forest Survey of India, available at: http: //fsi.nic.in/forest-fire.php (last access: January 2015), 2015.

Ganguly, D., Ginoux, P., Ramaswamy, V., Winker, D. M., Holben, B. N., and Tripathi, S. N.: Retrieving the composition and concentration of aerosols over the Indo-Gangetic basin using CALIOP and AERONET data, Geophys. Res. Lett., 36, L13806 doi:10.1029/2009GL038315, 2009.

Grieshop, A. P., Reynolds, C. C. O., Kandlikar, M., and Dowlatabadi, H.: A black-carbon mitigation wedge, Nature Geosci., 2, 533-534, doi:10.1038/ngeo595, 2009.

Gupta, S. and Narayan, R.: Brick kiln industry in long-term impacts biomass and diversity structure of plant communities, Current Sci., 99, 72-79, 2010.

Guttikunda, S. K. and Calori, G.: A GIS based emissions inventory at $1 \mathrm{~km} \times 1 \mathrm{~km}$ spatial resolution for air pollution analysis in Delhi, India, Atmos. Environ., 67, 101-111, doi:10.1016/j.atmosenv.2012.10.040, 2013.

Habib, G., Venkataraman, C., Shrivastava, M., Banerjee, R., Stehr, J. W., and Dickerson, R. R.: New methodology for estimating biofuel consumption for cooking: Atmospheric emissions of black carbon and sulfur dioxide from India, Global Biogeochem. Cy., 18, GB3007, doi:10.1029/2003GB002157, 2004.

Heierli, U. and Maithel, S.: Brick By Brick : The Herculean Task of Cleaning Up the Asian, Tech. Rep. FEBRUARY 2008, Natural Resources and Environment Division, Swiss Agency for Development and Cooperation, 2015.

Hendricks, J., Kärcher, B., Döpelheuer, A., Feichter, J., Lohmann, U., and Baumgardner, D.: Simulating the global atmospheric black carbon cycle: a revisit to the contribution of aircraft emissions, Atmos. Chem. Phys., 4, 2521-2541, doi:10.5194/acp-42521-2004, 2004.

ICAO: Environmental Report 2010, Tech. rep., International Civil Aviation Organization, 2010.

IEA: International Energy Agency Statistics, available at: http:// www.iea.org/statistics/ (last access: January 2015), 2012.

IPCC 2006: 2006 IPCC Guidelines for National Greenhouse Gas Inventories, Prepared by the National Greenhouse Gas Inventories Programme, edited by: Eggleston, H. S., Buendia, L., Miwa, K., Ngara, T., and Tanabe, K., IGES, Japan, 2006.

IPCC, 2013: Annex III: Glossary, edited by: Planton, S., in: Climate Change 2013: The Physical Science Basis. Contribution of 
Working Group I to the Fifth Assessment Report of the Intergovernmental Panel on Climate Change, edited by: Stocker, T. F., Qin, D., Plattner, G.-K., Tignor, M., Allen, S. K., Boschung, J., Nauels, A., Xia, Y., Bex, V., and Midgley, P. M., Cambridge University Press, Cambridge, United Kingdom and New York, NY, USA, doi:10.1017/CBO9781107415324.031.

ISMA: List of sugar mills in India, Bangladesh, Pakistan, Nepal \& Sri Lanka, Tech. rep., Indian Sugar Mills Association, New Delhi, India, 2012.

Ito, A. and Penner, J. E.: Historical emissions of carbonaceous aerosols from biomass and fossil fuel burning for the period 1870-2000, Global Biogeochem. Cy., 19, GB2028, doi:10.1029/2004GB002374, 2005.

Jain, N.: Emission of Air Pollutants from Crop Residue Burning in India, Aerosol and Air Quality Research, 14, 422-430, doi:10.4209/aaqr.2013.01.0031, 2014.

Janssen, N. A., Gerlofs-Nijland, M. E., Lanki, T., Salonen, R. O., Cassee, F., Hoek, G., Fischer, P., Brunekreef, B., and Krzyzanowski, M.: Health effects of black carbon, Tech. rep., World Health Organization, available at: http: //www.euro.who.int/en/health-topics/environment-and-health/ air-quality/publications/2012/health-effects-of-black-carbon (last access: April 2015), 2012.

Joshi, V.: Biomass burning in India, in: Global Biomass Burning: Atmospheric, Climatic, and Biospheric Implications, 185-193, The MIT Press, Cambridge, London, 1991.

Klimont, Z., Cofala, J., Xing, J., Wei, W., Zhang, C., Wang, S., Kejun, J., Bhandari, P., Mathur, R., Purohit, P., Rafaj, P., Amann, M., Chambers, A., and Hao, J.: Projections of $\mathrm{SO}_{2}, \mathrm{NO}_{x}$ and carbonaceous aerosols emissions in Asia, Tellus B, 61, 602-617, doi:10.1111/j.1600-0889.2009.00428.x, 2009.

Koch, D. and Del Genio, A. D.: Black carbon semi-direct effects on cloud cover: review and synthesis, Atmos. Chem. Phys., 10, 7685-7696, doi:10.5194/acp-10-7685-2010, 2010.

Kopp, R. E. and Mauzerall, D. L.: Assessing the climatic benefits of black carbon mitigation, P. Natl. Acad. Sci. USA, 107, 1170311708, doi:10.1073/pnas.0909605107, 2010.

Kumar, S.: Effective Waste Management in India, Tech. rep., INTECH CROATIA, 2010.

Lack, D. A., Corbett, J. J., Onasch, T., Lerner, B., Massoli, P., Quinn, P. K., Bates, T. S., Covert, D. S., Coffman, D., Sierau, B., Herndon, S., Allan, J., Baynard, T., Lovejoy, E., Ravishankara, A. R., and Williams, E.: Particulate emissions from commercial shipping: Chemical, physical, and optical properties, J. Geophys. Res.-Atmos., 114, D00F04, doi:10.1029/2008JD011300, 2009.

Lam, N. L., Chen, Y., Weyant, C., Venkataraman, C., Sadavarte, P., Johnson, M. a., Smith, K. R., Brem, B. T., Arineitwe, J., Ellis, J. E., and Bond, T. C.: Household light makes global heat: High black carbon emissions from kerosene wick lamps, Environ. Sci. Technol., 46, 13531-13538, doi:10.1021/es302697h, 2012.

Land Processes Distributed Active Archive Center (LP DAAC), 2000: MODIS MCD45A1, NASA EOSDIS Land Processes DAAC, USGS Earth Resources Observation and Science (EROS) Center, Sioux Falls, South Dakota, available at: https: //lpdaac.usgs.gov, last access: January 2015.

Lau, W. K. M., Kim, M.-K., Kim, K.-M., and Lee, W.-S.: Enhanced surface warming and accelerated snowmelt in the Himalayas and Tibetan Plateau induced by absorbing aerosols, Env. Res. Lett., 5, 025204, doi:10.1088/1748-9326/5/2/025204, 2010.
Li, X., Wang, S., Duan, L., Hao, J., and Nie, Y.: Carbonaceous Aerosol Emissions from Household Biofuel Combustion in China, Environ. Sci. Technol., 43, 6076-6081, doi:10.1021/es803330j, 2009.

Liousse, C., Penner, J. E., Chuang, C., Walton, J. J., Eddleman, H., and Cachier, H.: A global three-dimensional model study of carbonaceous aerosols, J. Geophys. Res., 101, 19411, doi:10.1029/95JD03426, 1996.

Lu, Z., Zhang, Q., and Streets, D. G.: Sulfur dioxide and primary carbonaceous aerosol emissions in China and India, 1996-2010, Atmos. Chem. Phys., 11, 9839-9864, doi:10.5194/acp-11-98392011, 2011.

Maithel, S., Uma, R., Bond, T., Baum, E., and Thao, V.: Brick Kilns Performance Assessment A Roadmap for Cleaner Brick Production in India, Tech. Rep. April, Greentech Knowledge Solutions, New Delhi, India, 2012.

Mathwave Technologies: Fitting tool EasyFit software, Tech. rep., available at: www.mathwave.com (last access: January 2015), 2015.

Meehl, G. A., Arblaster, J. M., and Collins, W. D.: Effects of black carbon aerosols on the Indian monsoon, J. Climate, 21, 28692882, doi:10.1175/2007JCLI1777.1, 2008.

Menon, S., Koch, D., Beig, G., Sahu, S., Fasullo, J., and Orlikowski, D.: Black carbon aerosols and the third polar ice cap, Atmos. Chem. Phys., 10, 4559-4571, doi:10.5194/acp-10-4559-2010, 2010.

Menzie, C. A., Potocki, B. B., and Santodonato, J.: Ambient concentrations and exposure to carcinogenic PAHs in the environment, Environ. Sci. Technol., 26, 1278-1284 doi:10.1021/es00031a002, 1992.

Ministry of Agriculture: Land Use Statistics Information System, available at: http://eands.dacnet.nic.in/ (last access: January 2015), 2011.

Ministry of Agriculture: Agricultural Statistics at a Glance 2013, Tech. rep., Directorate of Economics and Statistics, Government of India, New Delhi, 2013.

Ministry of Railways: INDIAN RAILWAYS Year Book 201011, Tech. rep., Government of India, New Delhi, available at: http://www.indianrailways.gov.in/railwayboard/uploads/ directorate/stat_econ/yearbook10-11/Year_book_10-11_eng.pdf (last access: July 2015), 2012a.

Ministry of Railways: INDIAN RAILWAYS ANNUAL REPORT \& ACCOUNTS, Tech. rep., Government of India, New Delhi, 2012b.

Ministry of Road Transport and Highways: Road Transport Year Book 2010-11, Tech. rep., Government of India, New Delhi, 2011.

Ministry of Steel: Annual Report 2012-13, Tech. rep., Government of India, New Delhi, 2014.

Mittal, L. M. and Sharma, C.: Anthropogenic Emissions from Energy Activities in India: Generation and Source Characterization (Part II: Emissions from Vehicular Transport in India), Tech. rep., available at: http://archive.osc.edu/research/archive/ pcrm/emissions/India_Report_1Pagelayout.pdf (last access: July 2015), 2003.

Moorthy, K. K., Beegum, S. N., Srivastava, N., Satheesh, S. K., Chin, M., Blond, N., Babu, S. S., and Singh, S.: Performance evaluation of chemistry transport models over India, Atmos. Environ., 71, 210-225, doi:10.1016/j.atmosenv.2013.01.056, 2013. 
MoPNG: All India Study on Sectoral Demand of Diesel \& Petrol, Tech. rep., Ministry of Petroleum and Natural Gas, Government of India, New Delhi, 2013.

MoPNG: Indian Petroleum and Natural Gas Statistics 2013-14, Tech. rep., Ministry of Petroleum \& Natural Gas Economics and Statistics Division, Government of India, New Delhi, 2014.

MoSPI: Energy Statistics 2014, Tech. rep., Central Statistics Office, Government of India, New Delhi, available at: http://mospi.nic. in/mospi_new/upload/Energy_Statistics_2013.pdf (last access: July 2015), 2014a.

MoSPI: Household Consumption of Various Goods and Services in India, Tech. Rep. 558, MOSPI, Government of India, New Delhi, 2014b.

Nair, V. S., Solmon, F., Giorgi, F., Mariotti, L., Babu, S. S., and Moorthy, K. K.: Simulation of South Asian aerosols for regional climate studies, J. Geophys. Res.-Atmos., 117, D04209, doi:10.1029/2011JD016711, 2012.

National Environmental Engineering Research Institute (NEERI): Air Quality Assessment, Emissions Inventory and Source Apportionment Studies: Mumbai, New Delhi, Tech. rep., Central Pollution Control Board (CPCB), 2010, 2010.

Ni, M., Huang, J., Lu, S., Li, X., Yan, J., and Cen, K.: A review on black carbon emissions, worldwide and in China., Chemosphere, 107, 83-93, doi:10.1016/j.chemosphere.2014.02.052, 2014.

Novakov, T.: Large historical changes of fossil-fuel black carbon aerosols, Geophys. Res. Let., 30, 1324, doi:10.1029/2002GL016345, 2003.

NSSO: Energy Sources of Indian Households for Cooking and Lighting, 2011-12, National Sample Survey Office,Ministry of Statistics and Programme Implementation, Government of India, New Delhi, available at: http://mospi.nic.in/mospi_new/upload/ nss_report_567.pdf (last access: May 2015), 2015.

Ohara, T., Akimoto, H., Kurokawa, J., Horii, N., Yamaji, K., Yan, $\mathrm{X}$., and Hayasaka, T.: An Asian emission inventory of anthropogenic emission sources for the period 1980-2020, Atmos. Chem. Phys., 7, 4419-4444, doi:10.5194/acp-7-4419-2007, 2007.

OpenStreetMap: OpenStreetMap Foundation - Geofabrik Data Downloads, available at: http://download.geofabrik.de/asia/ india.html (last access: April 2015), 2016.

Pachauri, T., Satsangi, A., Singla, V., Lakhani, A., and Maharaj Kumari, K.: Characteristics and sources of carbonaceous aerosols in $\mathrm{PM}_{2.5}$ during wintertime in Agra, India, Aerosol and Air Quality Research, 13, 977-991, doi:10.4209/aaqr.2012.10.0263, 2013.

Pandey, A. and Venkataraman, C.: Estimating emissions from the Indian transport sector with on-road fleet composition and traffic volume, Atmos. Environ., 98, 123-133, doi:10.1016/j.atmosenv.2014.08.039, 2014.

Pandey, A., Sadavarte, P., Rao, A. B., and Venkataraman, C.: Trends in multi-pollutant emissions from a technologylinked inventory for India: II. Residential, agricultural and informal industry sectors, Atmos. Environ., 99, 341-352, doi:10.1016/j.atmosenv.2014.09.080, 2014.

Parashar, D. C., Gadi, R., Mandal, T. K., and Mitra, A. P.: Carbonaceous aerosol emissions from India, Atmos. Environ., 39, 78617871, doi:10.1016/j.atmosenv.2005.08.034, 2005.

Parikh, S. and Radhakrishna, R.: India Development Report 200405, Tech. rep., Oxford University Press, New Delhi, India, 2005.
Pedersen, D. U., Durant, J. L., Taghizadeh, K., Hemond, H. F., Lafleur, A. L., and Cass, G. R.: Human cell mutagens in respirable airborne particles from the northeastern United States. 2. Quantification of mutagens and other organic compounds, Environ. Sci. Technol., 39, 9547-9560, doi:10.1021/es050886c, 2005.

Pessoa Júnior, A., de Mancilha, I. M., and Sato, S.: Evaluation of sugar cane hemicellulose hydrolyzate for cultivation of yeasts and filamentous fungi, J. Ind. Microbiol. Biot., 18, 360-363, doi:10.1038/sj.jim.2900403, 1997.

Press Information Bureau: Number of Steel Plants in India, Government of India, New Delhi, available at: http://pib.nic.in/newsite/ erelease. aspx?relid=77494 (last access: September 2015), 2011.

Qin, Y. and Xie, S.: Estimation of county-level black carbon emissions and its spatial distribution in China in 2000, Atmos. Environ., 45, 6995-7004, doi:10.1016/j.atmosenv.2011.09.017, 2011.

Quinn, P. K., Bates, T. S., Baum, E., Doubleday, N., Fiore, A. M., Flanner, M., Fridlind, A., Garrett, T. J., Koch, D., Menon, S., Shindell, D., Stohl, A., and Warren, S. G.: Short-lived pollutants in the Arctic: their climate impact and possible mitigation strategies, Atmos. Chem. Phys., 8, 1723-1735, doi:10.5194/acp8-1723-2008, 2008.

Rajarathnam, U., Athalye, V., Ragavan, S., Maithel, S., Lalchandani, D., Kumar, S., Baum, E., Weyant, C., and Bond, T.: Assessment of air pollutant emissions from brick kilns, Atmos. Environ., 98, 549-553, doi:10.1016/j.atmosenv.2014.08.075, 2014.

Ramachandra, T. V. and Shwetmala: Emissions from India's transport sector: Statewise synthesis, Atmos. Environ., 43, 5510 5517, doi:10.1016/j.atmosenv.2009.07.015, 2009.

Ramachandra, T. V., Aithal, B., and Sreejith, K.: GHG footprint of major cities in India, Renew. Sustain. Energy, 44, 473-495, doi:10.1016/j.rser.2014.12.036, 2015.

Ramanathan, V. and Carmichael, G.: Global and regional climate changes due to black carbon, 1, 221-227, doi:10.1038/ngeo156, 2008.

Reddy, M. and Venkataraman, C.: Inventory of aerosol and sulphur dioxide emissions from India. Part II - biomass combustion, doi:10.1016/S1352-2310(01)00464-2, 2002a.

Reddy, M. S. and Venkataraman, C.: Inventory of aerosol and sulphur dioxide emissions from India: I F Fossil fuel combustion, 36, 677-697, 2002b.

Reynolds, C. C. O. and Kandlikar, M.: Climate impacts of air quality policy: Switching to a natural gas-fueled public transportation system in New Delhi, Environ. Sci. Technol., 42, 5860-5865, doi:10.1021/es702863p, 2008.

Sadavarte, P. and Venkataraman, C.: Trends in multi-pollutant emissions from a technology-linked inventory for India: I. Industry and transport sectors, Atmos. Environ., 99, 353-364, doi:10.1016/j.atmosenv.2014.09.081, 2014.

Sahu, S. K., Beig, G., and Sharma, C.: Decadal growth of black carbon emissions in India, Geophys. Res. Lett., 35, L02807, doi:10.1029/2007GL032333, 2008.

Saud, T., Gautam, R., Mandal, T. K., Gadi, R., Singh, D. P., Sharma, S. K., Dahiya, M., and Saxena, M.: Emission estimates of organic and elemental carbon from household biomass fuel used over the Indo-Gangetic Plain (IGP), India, Atmos. Environ., 61, 212-220, doi:10.1016/j.atmosenv.2012.07.030, 2012.

Schultz, M., Backman, L., Balkanski, Y., Bjoerndalsaeter, S., Brand, R., Burrows, J., Dalsoeren, S., de Vasconcelos, M., Grodt- 
mann, B., Hauglustaine, D., Heil, A., Hoelzemann, J., Isaksen, I., Kaurola, J., Knorr, W., Ladstaetter-Weißenmayer, A., Mota, B., Oom, D., Pacyna, J., Panasiuk, D., Pereira, J., Pulles, T., Pyle, J., Rast, S., Richter, A., Savage, N., Schnadt, C., Schulz, M., Spessa, A., Staehelin, J., Sundet, J., Szopa, S., Thonicke, K., van het Bolscher, M., van Noije, T., van Velthoven, P., Vik, A., and Wittrock, F.: REanalysis of the TROpospheric chemical composition over the past 40 years. A long-term global modeling study of tropospheric chemistry funded under the 5th EU framework programme, Final Report, Tech. Rep. 3, Max Planck Institute for Meteorology, Hamburg, 2007.

Schultz, M., Rast, S., Pulles, T., Brand, R., Pereira, J., Mota, B., and Spessa, A.: Emission data sets and methodologies for estimating emissions, Tech. Rep. February 2007, Max Planck Institute for Meteorology, Hamburg, Germany, 2008.

Sen, A., Mandal, T., Sharma, S., Saxena, M., Gupta, N., Gautam, R., Gupta, A., Gill, T., Rani, S., Saud, T., Singh, D., and Gadi, R.: Chemical properties of emission from biomass fuels used in the rural sector of the western region of India, Atmos. Environ., 99, 411-424, doi:10.1016/j.atmosenv.2014.09.012, 2014.

Shakti Sustainable Energy Foundation: Diesel Generators: Improving Efficiency and Emission Performance in India, Shakti Sustainable Energy Foundation, available at: http://shaktifoundation.in/wp-content/uploads/2014/02/ Shakti-Diesel-Generators-FINAL1.pdf (last access: May 2015), 2014.

Shen, G., Yang, Y., Wang, W., Tao, S., Zhu, C., Min, Y., Xue, M., Ding, J., Wang, B., Wang, R., Shen, H., Li, W., Wang, X., and Russell, A. G.: Emission factors of particulate matter and elemental carbon for crop residues and coals burned in typical household stoves in China, Environ. Sci. Technol., 44, 71577162, doi:10.1021/es101313y, 2010.

Shen, G., Wei, S., Wei, W., Zhang, Y., Min, Y., Wang, B., Wang, R., Li, W., Shen, H., Huang, Y., Yang, Y., Wang, W., Wang, X., Wang, X., and Tao, S.: Emission factors, size distributions, and emission inventories of carbonaceous particulate matter from residential wood combustion in rural china, Environ. Sci. Technol., 46, 4207-4214, doi:10.1021/es203957u, 2012.

Sindhwani, R. and Goyal, P.: Assessment of traffic-generated gaseous and particulate matter emissions and trends over Delhi (2000-2010), Atmospheric Pollution Research, 5, 438-446, doi:10.5094/APR.2014.051, 2014.

Smith, K., Uma, R., Kishore, V., Lata, K., Joshi, V., Zhang, J., Rasmussen, R., and Khalil, M.: Greenhouse Gases from Smallscale Combustion Devices in Developing Countries, Phase IIA: Household Stoves in India, Tech. Rep. June, US Environmental Protection Agency, Office of Research and Development, Washington, DC 20460, EPA-600/R-00-052, 2000.

Sonkar, M.: Regional Scale Transport Simulation and Deposition of Elemental Carbon in the Himalayas: A WRF and CAMx Modeling, Ph.D. thesis, IIT Kanpur, 2011.
Streets, D. G., Gupta, S., Waldhoff, S. T., Wang, M. Q., Bond, T. C., and Yiyun, B.: Black carbon emissions in China, Atmos. Environ., 35, 4281-4296, doi:10.1016/S1352-2310(01)00179-0, 2001.

Streets, D. G., Yarber, K., Woo, J., and Carmichael, G.: An inventory of gaseous and primary aerosol emissions in Asia in the year 2000, J. Geophys. Res., 108, 8809, doi:10.1029/2002JD003093, 2003.

TERI (The Energy and Resources Institute): A Model to Establish a Policy Framework for Emissions Reduction, and costeffectiveness of Alternative Measures, Tech. rep., TERI, New Delhi, 2006.

Turn, S. Q., Jenkins, B. M., Chow, J. C., Pritchett, L. C., Campbell, D., Cahill, T., and Whalen, S. A.: Elemental characterization of particulate matter emitted from biomass burning: Wind tunnel derived source profiles for herbaceous and wood fuels, J. Geophys. Res.-Atmos., 102, 3683-3699, doi:10.1029/96JD02979, 1997.

Tyagi, R. C.: Problems and Prospects of Sugar Industry in India, Mittal Publications (India), 1995.

Venkataraman, C., Habib, G., Eiguren-Fernandez, A., Miguel, A. H., and Friedlander, S. K.: Residential biofuels in South Asia: carbonaceous aerosol emissions and climate impacts., Science (New York, N.Y.), 307, 1454-1456, doi:10.1126/science.1104359, 2005.

Venkataraman, C., Habib, G., Kadamba, D., Shrivastava, M., Leon, J.-F., Crouzille, B., Boucher, O., and Streets, D. G.: Emissions from open biomass burning in India: Integrating the inventory approach with high-resolution Moderate Resolution Imaging Spectroradiometer (MODIS) active-fire and land cover data, Global Biogeochem. Cy., 20, GB2013, doi:10.1029/2005GB002547, 2006.

Weyant, C., Athalye, V., Ragavan, S., Rajarathnam, U., Lalchandani, D., Maithel, S., Baum, E., and Bond, T. C.: Emissions from South Asian brick production, Environ. Sci. Technol., 48, 64776483, doi:10.1021/es500186g, 2014.

World Bank: Access to electricity (\% of population), available at: http://data.worldbank.org/indicator/EG.ELC.ACCS.ZS (last access: July 2016), 2010.

Yasunari, T. J., Tan, Q., Lau, K. M., Bonasoni, P., Marinoni, A., Laj, P., Ménégoz, M., Takemura, T., and Chin, M.: Estimated range of black carbon dry deposition and the related snow albedo reduction over Himalayan glaciers during dry pre-monsoon periods, Atmos. Environ., 78, 259-267, doi:10.1016/j.atmosenv.2012.03.031, 2013.

Yevich, R.: An assessment of biofuel use and burning of agricultural waste in the developing world, Global Biogeochem. Cy., 17, 1095, doi:10.1029/2002GB001952, 2003.

Zhang, Y., Shao, M., Lin, Y., Luan, S., Mao, N., Chen, W., and Wang, M.: Emission inventory of carbonaceous pollutants from biomass burning in the Pearl River Delta Region, China, Atmos. Environ., 76, 189-199, doi:10.1016/j.atmosenv.2012.05.055, 2013. 